\title{
대순사상의 종교 문화 조화정신
}

\author{
왕쭝 위 (王宗昱)
}

북경대학 · 교수

I. 상생 조화 정신

II. 종교 조화 정신

III. 민간신앙 및 신종교 수용

19세기의 동아시아 역사는 인류 역사상 매우 중요한 시기이다. 서 양 국가의 식민지 영역 확대와 군사적 침략은 동서문화의 교통을 격 렬한 방식으로 표현한 것이라 볼 수 있다. 20세기 후반기로 진입하면 서 군사적 충돌은 점차적으로 경제적 교류와 문화적 교류의 방식으로 전환되었다. 동아시아 산업 문명의 성과는 비서양권 문화 또한 새로운 전도가 있음을 설명하였다. 서양으로부터 온 자유시장 경제가 글로벌 화를 주도하였으나, 다원화 문제는 각국의 정치 지도자와 종교 지도자 들이 필히 해결해야만 하는 문제였다. 그로부터 백 년이 흐른 오늘날, 우리는 다원문화가 서로 병존하며, 종교적 화합이 전 세계 공동의 가 치가 되었음을 보고 있다.

한국은 백 년 이래로 군사적 침략과 경제적 대변혁을 맞았으며, 또 한 종교와 문화적 측면에서 전통의 중흥기와 서학의 유입에 대한 문 제를 경험하게 되었다. 이런 점에서 한국의 역사적 경험은 주변 국가 의 국민들이 배울 만한 의미가 있다고 생각된다. 이와 연관하여 대순 
진리회가 역사를 계승하고 창신을 이루어나가는 측면의 문제는 정리 해볼 만한 가치가 있다. 20세기 초기에 중국에서는 많은 신종교가 출 현하였고, 또한 전통종교에 대한 개혁 운동이 일어났으나, 이에 대한 중국 본토 학자들의 연구는 매우 미흡하다.1)

문외한인 필자가 대순사상의 바탕이 되는 전경』을 공부하는 과정에 서 얻어낸 자그마한 결과물을 종단 내외의 전문가들에게 바치니 많은 비판이 있기 바란다. 필자가 한국어를 알지 못하고, 중문으로 된 한국 의 연구논저에 대해서도 이해가 부족하므로, 실례를 범하는 점이 있을 지가 매우 걱정되며 이에 대해 교단 내 인사들의 많은 비평과 양해를 구하는 바이다.2)

\section{I. 상생 조화 정신}

이미 많은 학자들이 백 년에 이르는 한국 신종교의 유파와 역사적 분기에 관한 내용에 대해 매우 심도 있고 전면적인 연구를 진행한 바

1) 필자의 많지 않은 정보를 놓고보면, 국제 도교 연구 학자들은 새로운 시각에서 전통 종교와 유사해 보이는 새로운 사상에 대해 주의를 기울이고 있으며, 새로운 논제로 서 우리가 역사적 시간을 인식하는데 도움이 되도록 하고 있다. V. Goossaert and D.Palmer, The Religious Question in Modern China (The University of Chicago Press, 2011); V. Palmer and Liu Xun eds., Daoism in the Twentieth Century (University of California Press, 2011). 특히 일본 정계와 학계에서 전쟁 기간 동 안의 신종교 활동을 실질적으로 고찰하고 있음에 주목할 필요가 있다. 이에 대한 참 고 문헌은 아래와 같다. 興亞院政務部編, 『北支に於ける文教の現状(興亞院華北聯絡 部) 1941; 興亞宗教協會, 『華北宗教年鑒』(興亞院華北聯絡部, 1941). 그러나 이러한 자료에 대한 중국 학자들의 인식은 매우 부족한 상황이다.

2) 이러한 과정 속에서 필자 또한 한중 학자들의 저서를 공부하는 데 힘썼다. 김훈 교 수가 편집한 『道與東方文化』문집 중에 수록된 교우들의 글을 비롯하여, 김훈 교수 본인의 저작인 『韓國新宗教源流與嬗變』은 모두 이와 관련된 자료들이다. 한국 학자 인 盧吉明 교수 등이 편찬한 『韓國民族宗教運動史』 번역본 또한 필자에게 많은 도 움을 주었다. 본문에서 언급한 많은 역사 사건들에 관한 지식은 이러한 논저로부터 인용한 것이다. 학자들의 논저 및 자료로부터 필자는 많은 관련 지식을 얻었기에 이 에 깊이 감사드린다. 
있다. 증산 성사에 연관되어 개창된 교파는 한국의 근-현대 역사에 있어 매우 특수한 위치를 점유하고 있다. 여기에는 기타 종교와 관련 된 시대적 특징의 문제도 포함된다. 민족정신이 서려 있는 최수운의 동학은 결국 실패하였다. 후에 증산계열 종교의 지도자가 되는 많은 이들이 비록 동학 운동에 투신하였으나, 이들은 이후 자신들이 지향하 는 바가 동학과 다름을 표명하였다.

어떤 학자들은 이에 대해 아래와 같이 지적하고 있다. "대부분의 초 기 종교운동들은 '낡은 세계'의 종말과 '새 세계의 도래'를 희구하는 민 중의 열망을 바탕으로 전개되기 때문에 이와 같은 개벽이나 종말의 절 박성을 민중 동원의 주요 방법으로 삼는다.”3) 동학혁명의 결과는 매우 비참했다. 이와 연관하여 김홍철은 아래와 같이 말한 바 있다. "동학혁 명 이후, 이곳에서 등장한 증산교운동이야말로 이 지역의 역사적 배경 을 총체적으로 마무리 지어주는 민중종교운동의 대표적인 사례가 된다 고 할 수 있다. 증산의 가르침은 이 지역에서 필연적으로 다시 일어나 지 않으면 안될 민중의 또 다른 한과 저항의식을 녹아 내리게 하고 진 정한 후천선경(後天仙境)의 주인이 되게 하기 위해 우리 민중이 택해 야 할 바른 길을 제시해 주었던 가르침이었다고 보여진다.”4)

『전경』에서는 이에 대한 구천상제의 사상을 아래와 같이 기록하고 있다.

“본래 동학이 보국안민을 주장하였음은 후천 일을 부르짖음 에 지나지 않았으나 마음은 각기 왕후장상을 바라다가 소원을 이룩하지 못하고 끌려가서 죽은 자가 수만 명이라. 원한이 창천 하였으니 그 신명들을 그대로 두면 후천에는 역도에 걸려 정사 가 어지러워지겠으므로 그 신명들의 해원 두목을 정하려는 중 인데...”5)

3）『韓國民族宗教運動史』(中國社會科學出版社, 2009), p.35.

4) 같은 책, p.91.

5) 大巡宗教文化研究所編纂, 『典經』(여주: 大巡真理會出版部, 2010年版), p.117. 본문 에서 인용한 『典經』구절은 모두 이 판본으로부터 인용함. 
어떤 학자들은 증산계 신종교에 대해 외부 충돌의 극렬한 형식이 내재적 신비주의 형식으로 전환된 것이라고 말하기도 한다. 하지만 필 자는 이러한 완화와 전변이 증산 성사의 조화정신을 표현하고 있다고 생각한다. 특히 '해원상생' 사상은 이러한 조화정신을 집중적으로 나 타내고 있다. 대순진리회의 종지는 '음양합덕, 신인조화, 해원상생, 도 통진경'이다. 이러한 종지는 증산 성사의 사상을 충실하게 계승하고 있음을 보여준다. 또한 『전경』에서는 해원상생 사상이 매우 짙게 드러 나고 있다. 「공사」의 시작 부분에서는 해원상생에 관해 구천상제께서 설명하신 내용이 있다.

"선천에서는 인간 사물이 모두 상극에 지배되어 세상이 원한 이 쌓이고 맺혀 삼계를 채웠으니 천지가 상도(常道)를 잃어 갖 가지의 재화가 일어나고 세상은 참혹하게 되었도다. 그러므로 내가 천지의 도수를 정리하고 신명을 조화하여 만고의 원한을 풀고 상생(相生)의 도로 후천의 선경을 세워서 세계의 민생을 건지려 하노라. 무릇 크고 작은 일을 가리지 않고 신도로부터 원을 풀어야 하느니라. 먼저 도수를 굳건히 하여 조화하면 그것 이 기틀이 되어 인사가 저절로 이룩될 것이니라. 이것이 곧 삼 계공사(三界公事)이니라”6)

천지공사의 중요한 내용은 해원이다. 해원사상은 증산 성사와 관련 된 교단의 특징적 역사관을 나타낸다. 물론 이러한 사상은 다른 교단 에서도 나타나고 있는데, 이는 한국 신종교의 보편적인 사상이라 할 수 있으므로, 유구한 역사적 연원을 지니고 있다. 이에 대해 김훈 교 수는 이러한 문제가 한국 본토의 종교전통과 많은 연관이 있을 것이 라고 지적하고 있다.7)

해원에 대하여『전경』에서는 고대 전설의 예를 들어 설명하고 있다.

6) 같은 책, 94쪽. 金勳 교수의 저작 중에서도 이와 유사한 인용 구절이 있다. 『韓國新 宗教的源流與嬗變』(宗教文化出版社, 2006), p.139.

7）『韓國新宗教的源流與嬗變』，p.139. 


\begin{abstract}
“예로부터 쌓인 원을 풀고 원에 인해서 생긴 모든 불상사를 없애고 영원한 평화를 이룩하는 공사를 행하리라. 머리를 긁으 면 몸이 움직이는 것과 같이 인류 기록의 시작이고 원(冤)의 역 사의 첫 장인 요(堯)의 아들 단주(丹朱)의 원을 풀면 그로부터 수천 년 쌓인 원의 마디와 고가 풀리리라. 단주가 불초하다 하 여 요가 순(舜)에게 두 딸을 주고 천하를 전하니 단주는 원을 품고 마침내 순을 창오에서 붕케하고 두 왕비를 소상강에 빠져 죽게 하였도다. 이로부터 원의 뿌리가 세상에 박히고 세대의 추 이에 따라 원의 종자가 퍼지고 퍼져서 이제는 천지에 가득 차 서 인간이 파멸하게 되었느니라. 그러므로 인간을 파멸에서 건 지려면 해원 공사를 행하여야 되느리라.”8)
\end{abstract}

이러한 역사관은 인류가 근본적으로 세대의 원한을 풀어야만 행복 하고 안락한 시대에 진입할 수 있음을 설명하고 있다. 원한이 가득 찬 시대는 곧 선천이다. 최근에 대순종교문화연구소의 차선근 연구위원은 중국 고대의 해원 사상에 대한 연구를 한 바 있다.9) 그는 한대(漢代) 의『태평경』에서 말하는 '해원결(解冤結)' 사상과 대순진리회의 해원 상생(解冤相生) 사상을 비교하였는데, 이는 나에게 많은 영감을 안겨 주었다. 『태평경』의 저자는 역사상 매우 이른 시기에 ‘원결(冤結)’이라 는 말로써 사회의 모순을 설명하였고, '해원결'의 방법으로 집단 간의 충돌을 완화시킬 수 있다고 주장했다.

『태평경』에서는 흘러간 역사에 대해 특별히 해석하고 있지 않으며, 현재의 상황을 주목하고 있다. 『태평경』에 관해 전해 오는 최초의 설 에 따르면, 『태평경』은 사회의 운명을 바꾸기 위해 존재하는 것이 다.10) 이는 『태평경』의 종교 역사상의 의의가 곧 천지를 바꾸는 것에 있다는 것을 의미한다. 이런 의미에서, 『태평경』의 사상과 한국 근대

8)『典經』, p.125.

9) 그의 논문은 김훈 교수가 주편한 『道與東方文化』에 수록되어 있다.(宗教文化出版社, 2012년) 차선근 연구위원은 논문을 통해 정재서 교수가 1995년에『太平經』의 해원 사상에 관한 연구를 한 바 있다고 말하고 있다.

10)『漢書』, 第75卷, 中華書局標點本, 10 册, p.3192 참조. 
의 민족종교운동 중의 '개벽'사상은 일치한다. 또한 이렇듯 겁운을 변 화시키고자 했던 관념은 우리가 지속적으로 연구할 만한 가치가 있 다.11)

목전의 한국 근대 종교사상 연구 내용에는 일찍부터 전승되어 온 미륵 구세의 관념이 포함되어 있다. 사실 이러한 관념은 외부로부터 유입된 것이며, 동아시아의 본토 사상은 아니다. 천지를 개혁하는 사 상은 참위(識緯) 이전의 유가 경전에도 찾아볼 수 없으므로 그 기원을 찾는 것은 큰 가치가 있다고 하겠다.

『전경』 중 해원사상의 특징은 '상생'을 강조한다는 것이다. 차선근 이 '상생'의 이론에 대해 매우 상세한 서술을 하였으므로 필자가 이를 다시 중복하지는 않겠다. 이러한 '상생'사상은 당시의 갑오동학혁명과 구별될 뿐만 아니라, 역사상의 많은 종교에서 원한을 해결하는 방법과 도 구별된다. 차선근은 증산 성사의 해원에 대해서 강증산의 기본 사 상은 다가올 사람과 살아있는 사람을 대상한 것이라 하였다. "강증산 이 해원 하고자 하는 대상은 망자를 넘어서 살아있는 사람, 민족, 국 가, 심지어 동물과 신명 등 우주에 존재하는 모든 개체들에게까지 확 대된다"12)는 것이다. 증산사상과 기존 다른 사상과의 차이점은 해원 에 있어, 역사적으로 쌓여진 원한 뿐만 아니라 당대에 발생된 원한도 해원 해 준다는데 있다. 과거의 원한은 상극의 방법으로 해결할 수 있 었으나, 현대의 원한에 대해 만약 상극의 방식을 쓴다면 오히려 새로 운 원한을 더욱 증가시킬 수 있다고 하면서, 현대에 있어 원한을 제거 할 수 있는 방식은 “악을 선으로써 대하는 것”이라고 한다.

11) 노길명 교수는 특히 기독교의 천년왕국사상에 관해 논한 바 있다.(『韓國民族宗㸚運 動史』, p.33 참조) 프랑스의 도교 학자인 Anna Seidel는 기독교의 이러한 사상으로 중국 남북조 도교 및 당시 중국 북방의 민중 운동에 대한 비교를 진행한 바 있다. (The Image of the Perfect Ruler in Early Taoist Messianism, History of Religion 9:2, 1970) 이와 연관하여 필자가 중문으로 번역한 『老子和李弘』가 있는데, 이는 『國 際漢學』11집에 게재된 바 있다.(王宗昱譯, 中文本, 『老子和李弘』, 『國際漢學』第11輯, 大象出版社, 2004)

12）『道與東方文化, p.401. 
『전경』중에서 증산 성사는 종도들에게 이렇게 말하고 있다. "너희 들은 이제 마음을 돌리라. 이제 해원 시대를 당하여 악을 선으로써 갚 아야 하나니 만일 너희들이 이 마음을 버리지 않으면 후천에 또다시 악의 씨를 뿌리게 되니...”.13) 이를 볼 때, 증산 성사 및 그 후학들은 어떻게 새로운 사회 질서를 세울 것인가 하는 문제와 전통사회에서 인간 간의 조화를 방해하고 원한을 용인하는 구습을 개조하고 원을 소멸하는 문제에 주의를 기울였다. 『전경』에서는 또한 이와 연관된 증 산성사의 노력과 공헌에 대한 내용이 나타난다.

증산 성사께서는 겸용적 세계관을 수립하셨으며, 이에 대해 아래와 같이 말씀하셨다. "대개 나의 공사는 옛날에도 지금도 없으며 남의 것 을 계승함도 아니요 운수에 있는 일도 아니요 오직 내가 지어 만드는 것이니라. 나는 삼계의 대권을 주재하여 선천의 도수를 뜯어고치고 후 천의 무궁한 선운을 열어 낙원을 세우리라.”14) 삼계에 대해 언급하신 내용을 보아 알 수 있듯이, 증산께서는 우주적 차원에서 사상체계의 수립 문제를 고려하셨음을 알 수 있다. 예를 들면, 인존 사상은 삼계 의 관계에서 매우 중요한 내용이다. 선천의 도수를 개정한다는 것은, 증산 성사께서 역사적인 해원의 전통을 간단히 부정하는 것을 말하는 것은 아니며, 역사적인 원한을 없애는 것을 현대의 인류가 필히 준비 해야 할 조건으로 보고 있음을 설명한다. 그러므로 『전경』에서는 “명 부의 착란에 따라 온 세상이 착란하였으니 명부 공사가 종결되면 온 세상 일이 해결되느니라"15)라 하였다.

주목할 만한 사실은 증산의 개벽, 후천 사상이 조화의 정신을 나타

13) 『典經』, p.263.

14) 같은 책, p.94.

15) 같은 책, p.95. 『典經』에서는 증산께서 현대의 망자와 최수운의 원을 풀어주기 위 해, 만고역신의원을 풀어 주셨음을 기록하고 있다. 이렇듯 망자를 해원 하는 것은 역 사적으로 다른 종교에서도 그 전통을 볼 수 있다. 예를 들면 도교에는 총송(塚訟)의 원을 푸는 의식이 있다. 미국의 학자 Stephen Bokenkamp와 Nickerson 등은 이와 관련된 연구를 진행한 바 있다. Stephen Bokenkamp, Early Daoist Scriptures (University of California Press, 1997) 
내고 있다는 것이다. 먼저 증산께서는 전 세계적인 관점에서 민족과 국가 그리고 종교 간의 조화를 실현해야 할 것을 강조하셨다. 이와 연 관하여『전경』에서는 “상제께서 모든 도통신과 문명신을 거느리고 각 민족들 사이에 나타난 여러 갈래 문화의 정수(精敝)를 뽑아 통일하시 고”, “또 상제께서 가라사대 지기가 통일되지 못함으로 인하여 그 속 에서 살고 있는 인류는 제각기 사상이 엇갈려 제각기 생각하여 반목 쟁투하느니라. 이를 없애려면 해원으로써 만고의 신명을 조화하고 천지 의 도수를 조정하여야 하고 이것이 이룩되면 천지는 개벽되고 선경이 세워지리라」 하셨도다”16)라 하였다. 당시 동아시아 국가는 매우 폐쇄 적인 상황에서 서양 국가의 침략을 받던 시기였는데, 증산 성사께서 미래의 세계는 마땅히 화합을 이루고 서로의 장점을 배우는 세계가 될 것임을 예견하셨다는 것은 그의 위대함을 보여주는 부분이다. 오늘 날 우리는 글로벌화가 진행되는 과정과 전 세계가 30 여 년에 걸쳐 새 로운 변화를 이루었음을 보고 있는데, 이는 동아시아 공업 문명이 고 대 문화에 새로운 생기를 부여했음을 증명한다. 또한 이로써 서양 민 족은 점차적으로 공업 낙후 지역의 문화적 가치를 중시하고 있다.

다음으로, 증산 성사께서는 사람 간에 계층을 나눈다던가 원한이 쌓일 수 있는 전통적 구습을 제거하셨는데, 이러한 변혁은 평등의 관 념을 나타내고 있다. 이와 연관하여『전경』에서는 “상제께서 '지금은 해원시대니라. 양반을 찾아 반상의 구별을 가리는 것은 그 선령의 뼈 를 깎는 것과 같고 망하는 기운이 따르나니라. 그러므로 양반의 인습 을 속히 버리고 천인을 우대하여야 척이 풀려 빨리 좋은 시대가 오리 라' 고 하셨다"17)라 하였다. 조선시대의 양반 제도는 관료체계와 신 분 제도를 형성하게 하였다. 증산 성사께서는 당시 시대의 변화에 순 응하셨고, 전통적인 양반제도에 대해서는 “급이 낮고 먹기까지 고르지

16)『典經』, p.323, 125.

17) 같은 책, p.234. 
못하면 어찌 원통하지 않으리오?"18)라는 말로 의문을 제기하셨는데, 이는 명백히 사상적 혁명의 의미를 나타낸다. 이러한 사상은 구시대의 신분 관념을 없애야 할 것은 물론 인간의 평등을 주장한 것이다. 증산 성사께서는 귀천과 빈부 및 약자와 강자 등 사회적 차별이 사람 간의 원한과 모순을 조성한다고 보았다. 『전경』의 몇 군데 내용에서는 이러 한 문제에 대한 증산 성사의 명확한 관점을 말하고 있는데, 증산 성사 께서는 이러한 차별을 없애야 할 것을 말하고 있다.

이와 관련하여 증산성사께서는 “후천에서는 약한 자가 도움을 얻으 며 병든 자가 일어나며 천한 자가 높아지면 어리석은 자가 지혜를 얻 을 것이요"19)라 말씀하셨다. 이러한 주장은 당연히 그의 인존 사상과 밀접한 연관이 있다. 인존 사상은 새로운 시대의 인문주의이다. 사회 평등은 인존 사상의 한 측면을 말하는 것으로서, 평등은 곧 사람들 간 에 존재했던 충돌적 견해와 입장을 반성하고, 서로 간의 조화와 어울 림을 실현하는 것이다.

증산 성사의 구문화에 대한 개혁의 의지는 일상생활 측면의 세세함 에서도 표현되고 있다. 이에 대한 『전경』의 기록으로 “상제께서 고래 의 사제지간의 예를 폐지하시고, 종도들에게 평좌와 흡연을 허락하셨 도다.”20)라고 말씀하신 내용이 있다. 조선 왕조는 유교가 매우 발전 했던 시기였다. 유교는 허례허식의 번잡한 시속을 지녔음은 물론, 신 분제도라는 문화적 특징을 지녔다. 증산께서는 이러한 내용에 개혁을 단행했을 뿐만 아니라, 남녀 평등을 창도하였다.21) 결론적으로, 증산 께서 주창한 대순사상은 사람들 간의 충돌과 모순을 소멸시키고, 조화 와 상생의 사회 환경을 창조하고자 하는 것이었다.

18) 같은 책, p.258.

19) 같은 책, p.249.

20) 같은 책, p.82.

21) 같은 책, p. $105,246,258$ 참조. 


\section{II. 종교 조화 정신}

우리는 앞서『전경』에 소개된 증산 성사께서 “각 민족 문화의 정수 를 뽑아 통일”해야 한다는 내용을 본 바 있다. 또한 우리는 『전경』을 통해 증산 성사께서 어떤 종교에 대해 비판한 내용을 볼 수 있는데, 전체적인 의미에서 증산 성사께서는 각 종교에 대해 관용적인 태도를 표하셨고, 또한 매우 진지한 태도로 타 종교로부터 자신이 주창하는 사상과 관련한 자원을 흡수하셨다.

이와 관련하여『전경』에는 “상제께서 정유년에 다시 정남기의 집에 글방을 차리고 아우 영학과 형렬의 아들 찬문과 그 이웃 서동들을 가 르치셨도다. 이때에 유불선음양참위를 통독하시고 이것이 천하를 광구 함에 한 도움이 되리라 생각하시고...”22)라는 내용이 있다. 이러한 기 록은 증산 성사의 사상적 배경이 다원적임을 나타내며 그 배경이 조 선과 중국 역사상의 사상 자원임을 반영하고 있다.

중국의 역사에 있어, 속칭 유불선 ‘삼교’란 사회에서 보편적으로 인 정받는, 그 중에서도 특히 정부의 승인을 받은 종교를 말한다. 또한 ‘음양참위’란 서로 다른 시기, 서로 다른 지역의 사상의 함께 융합된 문화를 말하는데, 이는 정부의 승인을 받은 문화를 말하는 것은 아니 다. 예를 들면, '음양'은 지세와 민간 방술이 함께 융합된 것으로서, 한대(漢代)에는 황제가 이러한 참위 신학을 숭앙하였으나, 수대(隨代) 에 이르러서는 배척되고 심지에 금지되어 소멸되기까지 하였는데, 민 간에서는 매우 광범위하게 유전되었다. 한국의 종교 전통에서는 자주 '유불선'에 대한 내용을 말하고 있는데, 이는 중국인들이 일반적으로 말하는 '유도불'과 유사한 것이라 여겨진다. 이는 한국 또한 이러한 삼교를 사회적으로 중요한 위치에 있는 종교로 인식했음을 알 수 있

22) 같은 책, p.17. 이능화의 기록에 의하면, 늘 혼자 선도(仙道)의 태을주문(太乙呪文) 을 읽고 불전(佛典)의 칠성경(七星經) 및 유가서(儒家書)의 상서서(晌書序)를 고심 연구하여 진리를 발견코자 하였다.『朝鲜道敉史』(普成文化社出版), p.497 참조. 
다. 증산 성사께서도 예외는 아니셔서 역사상 습관적으로 거론되었던 것을 따르신 것으로 보인다.

신경원이 상제를 배알하기에 상제께서 그에게 “네가 올 것을 미리 알고 있었다”하시고 양지 한 장을 주어 유(儒) - 불(佛) • 선(仙) 자 곁에 석자를 쓰게 하시니라. 상제께서 유 자 곁에 이 구(尼丘), 불 자 곁에 서역(西域), 서나 자 곁에 고현(苦縣)이라 쓰시고 그 양지를 불사르셨도다. ${ }^{23)}$

이러한 기록은 증산 성사 또한 삼교를 가장 중요한 종교와 문화 형 태로 아셨음을 설명한다.

증산 성사께서는 “구천응원뇌성보화천존상제”로 신앙되었고 이는 도교적 요소의 중요성을 말하고 있지만, 필자는 여전히 그의 사상 체 계 속에 불교적 요소가 더욱 짙게 드러나고 있다고 여긴다. 필자의 말 이 과연 합당한가? 이에 대해 필자는 교단 인사들의 비판과 양해를 구하고자 한다.

『전경』 중에 나타난 사원은 적어도 십여 소가 된다. 그 중 가장 중 요한 사원은 당연히 금산사이다. 금산사는 증산 성사의 사상 전파와 밀접한 연관이 있다. 금산사는 한국의 역사로 본다면 매우 장구한 역 사를 지닌 불교 사원이다.24) 증산 관련 교단의 불교적 요소와 연관하 여 가장 중요한 구천상제의 위상에 관한 기록은 아래와 같다.

“상제께서 구천에 계시자 신성·불·보살 등이 상제가 아니 면 혼란에 빠진 천지를 바로잡을 수 없다고 호소하므로 서양(西 洋) 대법국 천계탑에 내려오셔서 삼계를 둘러보고 천하를 대순 하시다가 동토에 그쳐 모악산 금산사 미륵금상에 임하여 三十 년을 지내시면서 최 수운에게 천명과 신교를 내려 대도를 세우 게 하셨다가 갑자년에 천명과 신교를 거두고 신미년에 스스로 세상에 내리기로 정하셨도다”.25)

23)『典經』, p.84.

24）『韓國民族宗教運動史』, p.88.

25）『典經』, p.321. 
이에 대해 김홍철은 아래와 같이 말한 바 있다. "백제 멸망 후 그 유 민들이 진표율사(眞表律師)를 중심으로 일으켰던 미륵신앙운동은 20세 기까지 지속된다. 동학 운동과 증산교는 모두 이러한 운동이 외부로 표 출된 것이다"26) 한국의 학자들은 근대의 민족종교운동의 원류를 천 년 이상 거슬러 올라가는데, 이는 한국 종교사와 중국 종교사를 이해하는 데 매우 큰 영감과 도움을 준다. 이능화는 이러한 운동과 신앙을 "예수 의 재림”과 비교하고 있다.27) 필자가 여기기에 동아시아의 미륵신앙은 매우 유구한 역사를 지니고 있다. 이는 불교의 전래와도 매우 밀접한 연관이 있는데, 그러나 이는 일반적으로 우리가 아는 불교와는 또 다르 다. 미륵신앙은 미래세계에 대한 민중의 동경을 담고 있으며, 이는 또 한 현실에 대한 부정의 의미를 내포한다.

중국 역사에 있어서의 미륵신앙은 민간 비밀종교의 원류인데, 이는 매 세대의 광범위한 민중으로 하여금 미래에 대한 믿음을 갖게 하였 고, 천만 년간 고난에 빠진 민중들로 하여금 압제에 대해 반항심을 불 러일으키게 하였다. 1949년 이후 중국 대륙에서는 비밀종교에 대한 연구에 있어, 미륵신앙의 반항적 정신에 대해 너무 과도하게 주의를 집중하였는데, 일부 학자들은 이러한 신앙 운동과 연관한 자료에 대해 비교적 심도 있는 정리와 분석을 진행하였다. 마시샤(馬西沙) 교수의 연구에 의하면, 한말(漢末)에 불교 경전이 번역되어 중국에 유입된 상 황을 겪으면서 미륵에 대한 관념이 발생하게 된다. 서진(西晉) 시대에 는 불경 번역을 통해 확연하게 미륵정토신앙을 소개하고 있다. 이후, 미륵정토사상이 발전되는 상황 속에서 대량의 위조된 경전이 남발되 는 상황을 격게 되었는데, 이는 미륵구세신앙이 민간에서 광범위하게 유전되는 원인이 되었다. 미륵정토사상과 일반적인 불교사상의 차이는 전자가 “석가모니의 시기가 다하면, 새로운 불이 출현한다”28)는 내용

26) 『韓國民族宗教運動史』, p.89. 李能和는 『朝鮮道教史』에서 몇 차례에 걸쳐 조선시대 의 미륵하생 사건에 대한 역사적인 예를 들고 있다.

27) 『朝鮮道教史』, p.489. 증산께서도 자신을 미륵과 연관하여 말한 바 있다.『典經』, p.342 참조.

28 ) 이는 당현종 시기에 언급되었다. 그러나 '신불'은 북위(386-557) 시대에 이미 출 
을 주장하는 것에 있다.

『전경』 중에는 많은 불교 사원과 관련된 기록이 있는데, 이는 증산 성사 및 기타 제자들이 불교와의 왕래가 매우 잦았음을 말해 주며, 이 로써 볼 때 증산 성사와 그의 제자들이 불교와 매우 좋은 관계를 맺 고 있음을 알 수 있다. 그들은 또한 불교의 많은 교의와 의궤를 받아 들였다. 예를 들면, 『전경』에서는 증산 성사께서 제자들에게 "마음과 입과 뜻으로부터 일어나는 모든 죄를 조심하고”29)라 하였는데, 이를 통해 볼 때 불교의 관념을 매우 중요시했음을 알 수 있다. 그들은 또 한 불교 교단의 옳지 못한 행위에 대해 비판을 가하기도 하였다. 예를 들면, 증산께서는 송광사의 중들을 향해 “불법을 빙자하고 혹세무 민”30)한다고 하였다. 또한 어떤 불교 사찰은 그들이 자주 찾은 활동 장소이기도 하였다. 『전경』에서는 십여 처의 불교 사찰을 언급하고 있 다. 이 외에도 증산의 종도들 중 하나는 “미륵불교" 31 )를 내세우기도 하였다. 그러나 상술한 내용에도 불구하고 필자는 증산 성사와 종도들 이 불교에 속했다고는 생각하지 않는다. 중국의 경험상, 사찰에서의 종교 활동이 사찰의 칭호가 지닌 종교적 의미와 일치하는 경우가 많 기 때문이다.32)

또 다른 한편으로『전경』 내의 유가 사상은 몇 가지 의미를 내포하 고 있는데 관련 내용은 아래와 같다. 1. 증산 성사와 도주께서는 유가 의 경전을 매우 잘 이해하시고 있다. 2.『전경』을 통해 보건대, 증산 성사와 도주께서 알고 계시는 유파는 송대 이후의 이학파(理學派)이 다. 3. 두 분의 유가 사상에 대한 이해와 운용은 스스로의 창조성을

현하였다.(馬西沙, 『中國民間宗教簡史』，上海人民出版社， $2005 ，$ p.19 참조) 필자는 이능화가 미륵과 예수를 비교한 것을 반대하지 않으며, 이러한 구세주의 강림 신앙 은 중동, 페르시아로부터 인도에 이르기까지 모두 존재하였다. 이에 대한 최초의 원 류에 대해서는 필자 또한 알지 못하므로 역사학자와 종교학자들의 연구를 참고해야 할 것이다. 중국의 미륵신앙 또한 페르시아의 마니교와 결합된 것이라 볼 수 있다. 이에 대해서는 마시샤(馬西沙)와 린우슈(林悟殊)의 저서를 참고할 수 있다.

29) 『典經』, p.259.

30) 같은 책, p.6.

31）呂春燕、趙岩，『韓國的信仰和民俗』(北京大学出版社, 2010), p.266.

32）王宗昱，「清代漢中地區的全真道」， 丘處機與全真道』(中國文史出版社，2008） 
내포하고 있다. 『전경』의 많은 부분에서는 유가 경전의 내용을 인용하 고 있으며, 도주께서 사람들로 하여금 유가 경전을 수집하도록 했음 이 기록되어 있다.33) 그 중 가장 많이 언급된 유가 경전으로『주역』 과 대학』을 들 수 있다.

증산께서는 당시 역학의 대가이자 또 다른 신종교 지도자인 김일부 와 만난 적이 있었다.34) 이 외에도 조정산 도주 또한 법정에서 지방 의 법원장과 주역에 대해 논전한 바 있다고 한다. ${ }^{35)} 『$ 전경』 중에는 역학과 관련한 명사가 매우 많이 보이고 있는데, 이는 증산과 정산 두 분의 일상생활과 종교 활동이 역학과 매우 밀접한 관계를 지니고 있 음을 말해 주고 있다.

유가, 그 중에서도 특히 주자학은 조선왕조에 이르러 큰 발전을 이 루었다. 이는 당시 몇 백 년에 이르는 시간 동안 주자학이 조선반도에 서의 유학 형태에 영향을 끼첬음을 말해준다. 『전경』에 의하면, 증산 성사께서는 주희의 저서에 대해 매우 잘 알고 계셨다. 그는 또한 제자 들로 하여금 주희가 해석한 『대학』의 문구를 외우도록 명하셨다.36) 이것은 증산께서 이학의 역사를 숙지하고 계셨고, 이를 매우 중시하셨 음을 알려주고 있다.37) 또한 『전경』에는 “理雖高, 出於太極無極之表 不離乎日用事物之間[이치가 비록 높다 하나 태극(太極)과 무극(無極) 의 표현에서 나오므로 날마다 쓰는 사물 사이를 벗어나지 않는 법이 니라]"38)라는 증산께서 남긴 글이 있는데, 이는 곧 주희의 사상임을 알 수 있다. 『전경』에 기록된 많은 내용에서는 태극 혹은 태극도(太極 圖)에 관해 언급한 부분이 많은데 이 또한 주돈이(周敦頤) 일파의 후 학들이 말한 것이다.39)

33) 『典經』, p.225.

34) 같은 책, pp.17-18.

35）『韓國民族宗敉運動史』，p.23，174 참조.

36)『典經』, p.170.

37 증산의 사상을 계승한 정산의 “濂洛諸賢一時傳道”라는 글 역시 대순사상의 이학에 대한 인식을 잘 보여준다. 『典經』, p.208 참조.

38) 같은 책, p.319.

39) 태극도(太極圖)의 전승 및 도교와 유교의 관계에 대한 내용은 朱伯崑, 『易學哲學史 
중국에서 볼 수 있는 유가적 내용은 기본적으로 사상과 경전에 대 한 부분이며, 유가의 생활 예속에 관한 기록은 거의 없다. 예를 들면, 성복제40)에 대한 해석을 찾기 위해 필자는 『사고전서(四庫全書)』를 살펴보았으나, 성복제라는 말을 찾을 수 없었는데, 어쩌면 청조 말년에 성복제가 존재 했었는지도 모르겠다. 또 다른 한편으로 주희의『가례』 에서는 성복을 매우 중요한 상례의 내용으로 말하고 있으나, 특별한 제사 활동에 관한 내용은 찾을 수 없다.41) 『전경』에 기록된 유가 관 련 내용으로는 곡상(哭关), 제품(祭品), 그리고 죽은 자는 사대가 지난 이후 ‘귀(鬼)'가 된다는 것이 있다.42) 이는 증산의 사상과 그 이전의 종교 전통이 매우 밀접한 관계를 지니고 있음을 말해주며, 이와 연관 하여 한국의 유교 예속(禮俗)이 중국과 구별되는 부분을 연구하는 것 은 매우 가치가 있는 일일 것이라 생각된다.

이 외에도 특별히 주의할 만한 것은 『전경』에서 유가 경전의 치병 적 신앙에 관해 언급한 부분이다. 예를 들면, 어떤 사람이 복수병이 생긴 이후로 몸이 붓자, 상제께서는 그로 하여금『대학』의 문구를 염 송하게 하셨고, 이로써 그의 병은 곧 호전되었다. 『전경』에 소개된 또 다른 이야기로서, 육십사괘를 외우고 난 뒤, 다리 병이 나았다는 기록 이 있다.43) 이렇듯 유가 경전의 경문을 읽고 치병의 효과를 본 경우

(上冊, p.220, 中册, p.89, 北京大學出版社, 1986,1988 에 연이어 출판됨)을 참조하 기 바란다.

40) 『典經』, p.123.

41) 민간에서 유행한 상례에서 이러한 내용을 중시했음을 배제할 수 없다. 남송(南宋) 의 유재(劉宰)가 쓴 『漫塘集 에는 성복일에 사용하는 두 편의 제문이 수록되어 있 다.(『漫塘集』，第26卷，文淵閣四庫全書本 참조). 呂春燕，趙岩의 『韓國的信仰和民俗』 에서는 유가의 범주에 포함되는 한국 민간의 상장 전통에 대한 기록이 있는데, 성복 제를 독립적인 내용으로 다루고 있기도 하다. 이는 중국 학자들이 동아시아 상장문 명을 연구할 때 진지하게 토론할 만한 내용이라고 생각된다. 같은 책, p.296.

42)『典經』, pp.242-243. 사대가 지난 이후, 귀로 본다는 말은 중국의 경우 서진(西晉) 시대의 지우(摰虞)가 『결의요주(決疑要注)』에서 제시하였으나, 후대의 예서에서는 이 를 중요한 의제로 삼지 않았다. 지우의 책은 이미 소실되어 후대 사람들이 인용한 “사세위귀(四世為鬼)'라는 말 밖에는 볼 수가 없다. 필자의 추측으로는 주대(周代) 천자(天子)의 제사제도를 말하면서 이를 언급하였을 것으로 보인다. 이에 대해서는 『禮記 를 참고할 수 있다. 조선에서는 이러한 관념이 매우 유행하였는데 이는 유교 를 연구하는 역사 학자들이 주목할 가치가 있는 내용이라 생각된다.

43)『典經』, p.314, 309. 
가 있는가 하면, 경전의 주석을 염송하여 치병의 효과를 본 경우도 있 다.44) 이러한 치병은 경전의 신력에 의한 것이라고 해석될 수 있을 것이다.『전경』에서는 상제께서 어떤 이에게 "집에 가서 부치되 너는 칠성경(七星經)의 무곡(武曲) 파군(破軍)까지 읽고 또 대학(大學)을 읽 으라. 그러면 도에 통하리라" 45 라고 한 부분이 있다. 이렇게 볼 때, 유가 경전을 통해 효력을 얻는 것은 기타 경전을 읽어 효력을 얻는 것과 효과가 동일하다. 그러나 필자는 중국 본토에서 이와 유사한 기 록을 본 적은 없다. 말할 것도 없이『전경』에서는 이러한 내용을 통해 유가 경전이 지닌 교육적 작용을 더욱 집중적으로 말하고자 한다고 볼 수 있겠다. 상제께서는 “서전 서문을 많이 읽으면 도에 통하고 대 학 상장을 되풀이 읽으면 활연 관통한다”라 하셨으며, 상제의 부친께 서는 대학을 끊임없이 읽고 지혜가 밝아져서 마을 사람들의 어려움을 도와 준 일이 많았다고 한다. ${ }^{46)}$

필자는 「學曶『典經』筆記 47)에서 이미『전경』과 도교문화와의 관 계를 논한 바 있다. 『전경』 및 증산 성사의 사상과 활동에 있어서의 도교적 요소를 어떻게 분석해야 할 것인가? 이능화는 증산 성사의 사 적을 소개하면서 “늘 혼자 선도(仙道)의 태을주문(太乙呪文)을 읽고 불전(佛典)의 칠성경(七星經) 및 유가서(儒家書)의 상서서(佾書序)를 고심연구하여 진리를 발견코자 하였다"라 하였다. 또한 태을주에 대해 서는 “이 주문에 두 설(二說)이 있는데 같지 않다. 일설에는 강일순 (姜一淳)이 금강산에 들어가 불경을 공부할 때 한 도사에게서 얻은 것 이라 하고, 일설에는 황제(皇帝)가 지은 것을 노자(老子)가 수정한 것 이라 한다" 48 라 하였다. 이능화의 말에 근거해 볼 때, 태을주는 선도 의 범주에 속한다고 할 수 있을 것이며, 증산계 종교가 지닌 표식이자

44) 같은 책, p.306.

45) 같은 책, p.280.

46) 같은 책, pp.251-252.

47) 金勳이 主編한『道與東方文化』에 수록되어 있다.

48) 李能和, 『朝鮮道敉史』, p.498. 『典經』 의 154 쪽에서는 김경흔이라는 사람이 50년 간 수도하여 태을주를 얻었다는 대목이 있다. 이에 관한 내용은 『韓國民族宗教運動 史』, 23쪽에서도 볼 수 있다. 
선도의 표식이라 할 수 있을 것이다.

증산께서 “선(仙)” 자 옆에 고현(苦縣)을 쓴 것은,49) 고현이 노자의 고향이기 때문이며 이는 도교의 노자를 존중함을 표현한 것이라 할 수 있다. 그러나 증산께서는 스스로 자신이 미륵이라 하였으며,50) 이 후 도주에 의해 구천응원뇌성보화천존상제로 존칭되었다.51) 이를 볼 때, 증산은 확연히 자신의 사상을 도교만을 배경으로 전개하지는 않은 것 같다. 그러나 필자가 보기에는 증산 성사의 사상은 도교적 색채가 매우 짙다고 생각된다. 이는 증산께서 표방한 이상사회가 '선경'을 건 설하는 것임을 보아도 알 수 있다. 이와 관련하여 증산께서는 “나를 좇는 자는 영원한 복록을 얻어 불로불사하며 영원한 선경의 낙을 누 릴 것"52)이라 하신 바 있다.

그는 왜 자신을 미륵이라 칭하면서 이와 동시에 사후에 도교의 신격 을 지니게 되었던 것일까? 이는 연구해 볼 만한 가치가 있는 내용이다. 보화천존이라는 칭호는 조선시대에 유전되었던 『옥추경』과 직접적인 관 계가 있어 보인다. 이능화의 조선도교사를 보면 이에 대해 언급한 내용 이 있는데, 증산께서 사용한 태을주는 태을원군을 향해 기도하는 주문 이다. 이 신에 관한 기록은 중국 진대 갈홍의 포박자에서 볼 수 있다.

『전경』에 기록된 『현무경』 또한 증산 성사와 현무신앙의 연관성을 시사한다. 중국에서의 현무신앙에 관한 역사는 매우 유구하나 도교에 속하지는 않는다. 그러나 북송과 명대에 황족들이 인도네시아 화인 사 회에 이를 전파하면서 지금에 이르기까지 동남아시아 지역에서 많은 영향을 끼치고 있다. 『전경』에『현무경』 전문이 실려 있지 않아서 자세 한 내용은 알 수 없으나, 기타 다른 지역의『현무경』 신앙과 다른 점이 있을 것이라 생각된다. 『전경』 소개된 『현무경』의 내용 중에는 유가 경 전의 목록을 포함하고 있는데, 이를 통해『전경』중의『현무경』은 중국

49)『典經』, p.84.

50) 같은 책, p.22.

51) 같은 책, p.210.

52) 같은 책, p.279. 
『정통도장』 중에 수록되어 있는 몇 편의『현무경』 내용과 근본적으로 차이가 있음을 알 수 있다. 그러나 필자는 우선 이를 선도에 근접한 것이라 보기로 한다.

『전경』의 내용을 보면 도교적 언어가 매우 많다. 중국과 조선은 오 랜 시간의 역사적 과정 속에서 서로 간에 영향을 끼쳐 왔으며, 이러 한 문자들은 이미 동아시아가 지닌 공동의 자원이 되었다. 예를 들 면, 『전경』에서는 증산께서 출생하신 지역에 역사적으로 삼신산(三神 山)이 있었음을 말하고 있다.53) 이런 것들은 해산(海山), 선산(仙山)과 관련한 오랜 전설이라고 할 수 있을 것인데, 이는 중국, 조선, 일본이 공동으로 지닌 문학, 종교의 유산이라 할 것이다. 『전경』의 행록 제 2 장 에서는 김일부가 꿈에 '천상옥경'으로 가서 천존을 배알하는 대목이 있다.54) 이는 도교의 신앙에서 온 것이 분명해 보인다. 옥경산과 삼 십육 천이라는 말은 중국의 남북조시기에 형성된 것이며, 이는 가장 높은 천계를 일컫는 것이다.

『전경』에는 예수교와 서양 문화에 관한 내용 또한 매우 많다. 특히 이마두를 서양문화를 대표하는 자라 하여 그에게 매우 높은 지위를 부여하고 있다.55) 학자들의 연구에 따르면, 이마두는 한국에 온 바가 없으며, 그의 제자 서광계가 1620 년에 한국에 올 계획은 있었다고 전 한다. 1603년 조선의 사절이 북경으로부터 이마두가 제작한 지도를 가져 왔었으며,56) 이 때 이마두는 아직 살아 있었다. 1613년에 정두 원이 중국으로 와서 이마두의 『천주실의』 등의 서적을 가지고 갔 다.57) 1783 년에는 이승훈이 부친과 함께 중국으로 와서 중국에 있는 기간 동안 세례를 받았는데, 귀국 후에 양반 제자들로 하여금 천주교 에 입교토록 하였다. 이후, 신도들이 30여 명 이상이 되자, 조선 교회 가 세워졌다. 서양의 학술이나 종교를 막론하고 조선인들이 접한 최초

53) 같은 책, p.2.

54) 같은 책, pp.17-18.

55) 같은 책, p.172.

56）李元淳, 『朝鮮西學史研究』(中國社會科學出版社, 2001), p.74.

57）王春來，『基督教在近代韓國』（中國社會科學出版社，2000）, p.7. 
의 정보는 모두 이마두와 관련이 있다.

그러나 증산교 관련 교단과 마찬가지로 기타 신종교에서도 이마두 가 이처럼 중요한 위치를 차지하는 지는 더 많은 자료를 수집해 봐 야 할 것 같다. 필자는 아직까지 많은 자료를 구하지 못했다. 그러나 『전경』을 통해 볼 때, 증산께서는 이마두에 대해 정확한 역사적 평가 를 하고 있다.

“서양인 이마두(利瑪賔)가 동양에 와서 지상 천국을 세우려 하였으되 오랫동안 뿌리를 박은 유교의 폐습으로 쉽사리 개혁 할 수 없어 그 뜻을 이루지 못하였도다. 다만 천상과 지하의 경 계를 개방하여 제각기의 지역을 굳게 지켜 서로 넘나들지 못하 던 신명을 서로 왕래케 하고 그가 사후에 동양의 문명신(文明 神)을 거느리고 서양에 가서 문운(文運)을 열었느니라. 이로부터 지하신은 천상의 모든 묘법을 본받아 인세에 그것을 베풀었노 라. 서양의 모든 문물은 천국의 모형을 본뜬 것이라.” ${ }^{58)}$

『전경』에서는 증산을 비롯한 그의 제자들과 예수교도와의 몇 차례 유쾌하지 못했던 교류를 기록하고 있으며, 또한 이에 대해 부정적인 평가를 하고 있다.59) 그러나 상술한 『전경』의 내용을 통해 볼 때, 증 산께서는 제자들을 이끌던 사상적 지도자로서 서양문화를 포용하는 입장을 보이고 있다. 그의 입장에서 볼 때, 서양의 문화는 그가 건립 하고자 하는 신세계의 한 부분이다. 몇 번의 대화 내용을 통해 볼 때, 증산께서는 서양문화를 유불선 삼교와 그 의미를 나란히 하는 문화적 요소로 보고 있는 듯하다. 이는 증산께서 당시 세계의 역사적 방향에 대해 통찰하고 있었고 이 통찰 속에서 종교 간의 관계가 조화롭게 되 어야 함을 주창했음을 말해 준다. 증산께서는 심지어 “선도(仙道)와 불도(佛道)와 유도(儒道)와 서도(西道)는 세계 각 족속의 문화의 바탕 이 되었나니"60)라 하였던 것이다.

58)『典經』, pp.147-148.

59) 같은 책, p.40, 252.

60) 같은 책, p.172. 


\section{III. 민간신앙 및 신종교 수용}

대순사상의 중심 체계는 중국의 삼교 융합 체계와 유사하다고 볼 수 있다. 이와 관련하여『전경』에서는 증산의 말을 아래와 같이 기록 하고 있다.

“내가 도통줄을 대두목에게 보내리라. 도통하는 방법만 일러 주면 되려니와 도통될 때에는 유 불 선의 도통신들이 모두 모 여 각자가 심신으로 닦은 바에 따라 도에 통하게 하느니라.”61)

필자가 생각건대 이는 상부에 속한 종교 지도자의 사상 체계이다. 넓은 하층의 민중들에게 가르침을 펴기 위해서는 그들이 필요로 하는 것을 만족시켜야만 한다. 미륵신앙의 내용에서는 정통 불교의 관념이 아니라, 미래의 구세주가 속세에 강림하여 중생을 구제할 것이라고 말 한다. 또한 참위와 후천의 개벽사상 또한 민중의 바람에 순응하는 것 이라고 볼 수 있다. 후천개벽사상은 전통적 참위를 현대적으로 개조한 것으로 민중을 적극적으로 인도하기 위한 것이다. 필자로서는 이와 관 련된 역사적 지식이 매우 부족하므로 몇 가지만 서술해 보고자 한다.

먼저, 증산의 활동과 민간 무교의 관계에 대해 살펴보자. 『전경』에 서는 이와 관련하여 아래와 같은 기록이 있다.

“상제께서 김경학의 집에 대학교를 정하시고 '학교는 이 학교 가 크니라. 이제 해원시대를 당하였으니 천한 사람에게 먼저 교 를 전하리라'하시고 경학을 시켜 무당 여섯 명을 불러오게 하고 그들의 관건을 벗기고 각자 앞에 청수를 떠놓고 그것을 향하여 사배를 하게 하고 시천주 세 번을 제각기 따라 읽게 하셨도다. 이것을 끝내고 그들의 이름을 물은 다음에 각자로 하여금 청수 를 마시게 하니 이것이 곧 복록이로다. 이것이 해원시대에 접어 들어 맨 먼저 천한 사람들에게 교를 전하신 것이었도다.”62)

61) 같은 책, p.162. 
상술한 내용은 사실상 증산께서 지방 종교를 개편하는 것과 관련이 있다. 증산은 또한 무당의 의례를 차용하여 그 종교 행위를 전개하기도 하였다. 이와 연관하여 『전경』에는 상제께서 “무당 도수를 행하신” 63$)$ 것을 기록하고 있다. 증산께서는 또한 고사의식을 행하는데 능하셨는데, 고사는 한국 민간에서 보편적으로 유행하던 전통적 종교 의식이었다.64)

다음으로, 증산의 사상은 민간에서 유행했던 다양한 신령 숭배의 내용을 흡수하고 있다. 예를 들면, 상제께서는 부(符)를 쓰셔서 '도로 신장'이 도움을 줄 것을 명령하신다.65) 이러한 류의 신명은 민간에서 오랫동안 유전되었던 숭배 대상으로서 부뚜막신, 사명, 아표신, 마장 군, 백의군왕, 황천신 등이 이에 속한다. 증산의 사상은 이러한 민간 신앙의 내용들을 포함하고 있으며, 이러한 신앙들과 관련된 각종 법술 의 내용 또한 포함하고 있다.

이러한 법술은 또한 주문과 부를 태우는 방법으로 신명과 관련된 내용을 표현하고 있다. 『전경』을 통해 볼 수 있는 주문은 약 20종 이 상에 이르는데, 이러한 주문은 그 내력이 서로 다르다. 필자는 이전에 구령삼정주가 도교의 주술로부터 기인하였음을 말한 바 있는데, 『전경』 중에는 당연히 시천주와 같이 새로이 창조된 주문도 포함되어 있다. 이러한 주문 중에는 또한 민간신앙으로부터 온 것도 있는데, 예를 들 어 오방주는 둔갑과 연관이 있는 것으로 보인다.66) 『전경』 중에 언급 된 주문들은 매우 복잡하면서도 체계가 있는데, 이는 민간에서의 간단 하고도 쉬운 주문들과는 다르다. 주문에 대한 필자의 이해가 부족하므 로 주문 중의 일부가 민간에서 장기간 유전된 신앙에서 기인한 것일 수도 있음을 배제할 수 없다고 생각된다. 이 외에도, 부의 신력에 대

62) 같은 책, pp.159-160.

63) 같은 책, p.138.

64) 같은 책, p.77; 『韓國的信仰與民俗』, p.243 참조.

65) 『典經』, p.279.

66) 같은 책, p.220. 文淵閣四庫全書本인 『遁甲演義』을 참고할 수 있다. 浆梧의 논문 중 에『典經』 중의 遁甲에 대해 초보적 연구를 진행한 것이 있다. 『道與東方文化』 참조. 
한 숭배의 문제는 인류의 오랜 신앙과 연관된다고 생각된다. 『전경』에 서는 신앙치료에서 신부(神符)를 사용하는 많은 실례를 들고 있으므로 본고에서는 이 부분을 잠시 접어두도록 한다. 증산의 사상은 이러한 민간 신앙적 요소를 흡수하면서 하층 민중들의 바람을 만족시켰는데, 이는 전교가 용이하도록 하였을 뿐 아니라, 증산사상이 보다 광대하게 영향을 미칠 수 있도록 하였다.

이 외에도 필자는 칠성과 관우의 신앙을 본고의 내용과 연관하여 말하고자 한다. 필자로서는 중국과 조선시대에 칠성과 관우에 대한 신 앙의 종교적 특징이 어떠하였는지를 확연히 말하기 어렵다. 다만 앞서 한국의 학자들이 칠성경을 불교의 범주에서 다루고 있음을 소개한 바 있다. 이능화의『조선도교사』에서는 한 장에 이르는 지면에 걸쳐, 칠 성의 문제를 다루고 있다. 이능화는 칠성신앙을 도교와 불교가 혼합된 현상이라 보았다. 그는 조선의 불교 사찰에 칠성각이 있는 경우가 많 으며 또한 이와 관련된 전문적인 의식이 있었다고 말한다. 이능화는 또한 황가에서 칠성에 관한 제의를 행할 때, 맹인들이 경을 송독하였 는데, 이를 “도류의 체계” 67$)$ 라고 말한 바 있다. 필자는 최근에『전경』 을 통해 칠성신앙에서 칠성경이라는 주문의 송독이 중요한 것임을 알 게 되었다. 이것이 어떤 종류의 종교에 속하는 것인지는 판단하기 어 려우므로 이를 민간신앙으로 귀결시킬 수밖에 없다고 생각된다. 이능 화는 민간에서 장례를 치르면서 관을 묻을 때에 칠성판을 사용한다고 하였으며,68) 이로써 칠성신앙의 기원을 알아보고자 하였다. 필자는 이능화의 노력으로 우리가 많은 것을 알게 되었다고 생각하는데, 민간 에서의 칠성신앙의 유전 문제는 토론해 볼 가치가 있다고 보여진다.

최근 학계에서는 관운장에 관한 연구에 있어 관우신앙과 불교의 관

67) 李能和는 “『李朝實錄』에 의하면, 세종대왕의 어머니가 병이 나자, 맹인 승려(道流 僧)들이 도지정근(桃枝精勤)을 행했는데 이는 맹인이 독경을 한 원류가 되었다”라 하였다.『朝鮮道教史』, p.464.

68)『朝鮮道教史』, p.477. 이능화가 관목에 칠성판을 사용한 것에 대한 예를 든 것은 조 기의 것이라 보기 어려우며, 이에 대한 시기는 『顏氏家訓까지 거슬러 올라가야 할 것이다. 
계를 연구하는 것에 비교적 주의를 집중하고 있다.69) 러시아의 한학 자(漢學家)인 리푸칭(李福淸) 교수는 많은 지방의 전설을 수집하였다. 그는 관우신앙을 민간에서 광범위하게 전파된 신앙이라 보고, 어떤 교 단이 관우신앙을 흡수하였는지는 중시하지 않는다. 관우는 후에 무성 인(武聖人)으로 숭배되면서 공자와 어깨를 나란히 하였는데, 이로써 볼 때 관우신앙이 매우 강한 독립성을 지니고 있음을 알 수 있다. 최 근 중국의 민간에서는 상업적 인사들이 그를 재신(財神)으로 섬기고 있으며, 많은 민간의 교단 특히 부란(扶鸞)을 신앙하는 현대 종교에서 는 관운장을 신앙하는 것이 매우 영험하다고 믿고 있다. 최근에 중국 의 학자인 쏜웨이꾸어(棌衛國)는 『朝鮮王朝關王廟創建本末與關王崇拜 之演變』이라는 글을 발표하여, 관우신앙이 조선에 진입한 것에 대해 매우 상세한 고찰을 진행하였는데, 배울 부분이 많다고 본다. 그는 관우신앙이 대략 명조의 군대를 통해 조선으로 유입되었다고 말한다. 1597 년, 중국 군인들의 필요에 의해 명조의 군대는 지금의 고도(古 島)에 처음으로 관제묘를 설립하였다.70) 이후, 조선의 황제는 중국과 의 관계를 강화하기 위하여 관제 숭배를 국가의 제사에 포함시켰다. 쏜웨이꾸어는 관제 숭배에 대한 내용을 3 단계로 나누었다. 제 1 단계는 조선에 관공 신앙이 수립된 시기이며, 제2단계는 번영 발전기이며, 제 3 단계는 민간으로 전파됨과 동시에 본토화가 이루어지는 시기이다. 제3시기는 대략 1801 년을 시작으로 하는데, 어쩌면 민간에서의 시기 가 더욱 빠를 수도 있다. 『전경』의 기록을 보게 되면, 관운장은 증산 성사가 중요시한 신으로 증산의 종도들로부터 숭배를 받았는데 이는 곧 영험함 때문이었다. 『전경』에 기록된 두 군데의 관제묘는 모두 사

69) 관공의 신앙에 관한 연구 상황은 周努魯의「關炣信仰研究的回顧與探討」, 中國人民 大學 刊, 『宗呚㸴究 (宗教文化出版社出版, 2012年刊)를 참고할 수 있다. 盧曉衡가 주편한『關狋、關公和關聖』(社會科學文獻出版社, 2002)에서도 관공 연구에 관한 논 저와 목록을 수록하였다.

70) 2013년 8월 북경대학에서 주최한 학술회의에서 한국 학자 김일권이 발표한「朝鮮 後期關聖教的敬信修行論」 은 필자에게 많은 정보를 제공하였다. 『韓國侀究論丵』第22 輯（世界知識出版社, 2010), p.39. 
회적으로 개방된 관제묘로서 당시 증산 소유의 것은 아니었다. 이것은 다양한 경로를 통해 관운장이 숭배 받았음을 알려준다. 증산 성사는 그의 종도들에게 관운장에게 제사를 올리면 도움을 줄 것임을 믿게 하였다. 소위 일컫는 “운장주”는 관운장과 기타 신장이 자신을 보호하 게 하며, 악귀 잡귀를 물리치게 하는 주문이다.71)

마지막으로, 증산 성사와 동학운동의 관계에 대해 말하고자 한다. 『전경』에서 증산 성사와 관계를 지닌 교단 중 가장 많이 거론된 종교 단체는 동학이다. 증산 성사와 그의 제자들은 동학의 성원들과 자주 내 왕하였다.72) 또 다른 한편으로, 동학의 주문인 “시천주”는 증산 성사와 그 제자들이 자주 사용하던 것이었다. 증산께서 새로운 종교 운동을 일 으킨 이후, 일부 제자들은 동학당에 대해 매우 부정적인 견해를 가지고 되었으므로,73) 상호 간에 거리가 생기게 되었다. 그러므로 증산 성사의 종교운동 발전과 동학 조직은 매우 밀접한 연관을 갖고 있다.

증산께서는 동학 운동에 대해 변증의 견해를 지니고 계셨는데, 이 와 연관된 『전경』의 내용은 아래와 같다. "난을 짓는 사람이 있어야 다스리는 사람이 있나니 치우(䖧尤)가 작란하여 큰 안개를 지었으므로 황제(黄帝)가 지남거(指南車)로써 치란하였도다. 난을 짓는 자나 난을 다스리는 자나 모두 조화로다. 그러므로 최 제우(崔濟愚)는 작란한 사 람이요 나는 치란하는 사람이니라. 전 명숙은 천하에 난을 동케 하였 느니라.”74) 그는 전명숙을 고금의 명장의 범주에 포함시켰는데, 이로 볼 때 증산 성사께서는 동학 운동 및 그 지도자들의 역사적 지위를 매우 높게 평가했음을 알 수 있다. 동학의 교조인 최수운을 신계의 선 도 종장 및 일본 명부로 임명한 것 역시 같은 맥락이다. 비록 증산은 동학에 대해 강하게 비판하기도 하였지만, 그럼에도 불구하고 그가 최

71)『典經』, p.294, 155.

72) 盧吉明은 증산교는 “동학운동이 가장 활발히 전개 되던 장소에서 일어났는데, 이 로 볼 때 동학 혁명을 일으킨 성원을 중심으로 발전했음을 알 수 있다”라 하였다. 『韓國民族宗教運動史』, p.8.

73)『典經』, p.253 참조.

74) 같은 책, p.269. 
수운을 높이 평가한 점이라던가 동학당원을 제자로 받아들인 점들을 미루어 볼 때 그는 단지 동학에 대해 회유나 이용만은 하지 않았음을 알 수 있다. 다시 말해, 증산 성사의 종교 활동은 동학 혁명의 비참한 최후를 완화시켰던 위대한 역사적 공적이라 할 것이다. ${ }^{75)}$ 그는 많은 동학의 자원을 받아들였는데, 예를 들면 “시천주”, “수운가사” 및 “육 임”76)제도 등이 그것이다. 증산 교문에 잔존했던 동학당원의 좋지 않 은 시습을 고치기 위해 증산 성사께서는 스스로의 행동을 통해 그들 을 감화시켰다.77) 이는 신종교 운동의 사회적 형태를 변화시켰을 뿐 아니라, 서로 다른 내력을 지닌 교도들 간의 관계를 조화롭게 하였다.

75）『韓國民族宗教運動史』，p.91 참조.

76)『典經』, p.331.

77)『典經』의 151쪽에는 상제께서 자신의 재산을 팔아 거지에게 나누어 준 기록이 있 으며, 이로써 일진회원들을 감화시켜 그들이 갑오에 민간의 재산을 약탈했던 악습을 고치도록 하였다. 

『대순사상논총』제22집

대순사상학술원, 2014, pp.113 131

\section{大巡思想中的宗教文化和谐精神}

王宗昱

北京大学・教授

二、相生与和谐精神
二、宗教文化和谐精神

三、对民间信仰与新宗教的包容精神

十九世纪的东亚历史在人类历史上是一个重要的时期。西方国家的殖民 扩张和军事侵略以激烈的方式表达了东西文化的交通。进入二十世纪后牛 叶, 军事的冲突逐渐转变为经济的交流和文化的交流。东亚工业文明的成 就说明非西方的文化也有自己的新的前途。尽管来自西方的自由市场主导 了全球化，但是多元化成为各国政治领袖和宗教领袖必须解决的问题。一 百多年以后的今天，我们看到文化多元并存、宗教和谐成为全世界共同的 价值取向。

韩国一百年来遭受了军事的侵略和经济的大变革，也在宗教和文化方面 有很多复兴传统和引进西学的经验。韩国的历史经验很值得周边国家的人 民学习。大巡真理会在继承历史和创新建设方面也有很多经验值得我们总 结。中国在二十世纪初期同样出现了许多新兴宗教和传统宗教的改革运 动，但是中国本土学者对此还很少有研究1）。

1）据本人知之不多的信息，某些国际道教研究的学者开始从新的视角注意这些貌似传统宗教的 新内容，从而开辟了一些新的论题帮助我们认识那段历史。V. Goossaert and D. Palmer, The Religious Question in Modern China (The University of Chicago Press), 2011. V. Palmer and Liu Xun eds., Daoism in the Twentieth Century (University 
本人作为一个门外俗人, 在学习大巡思想之基础的『典经』的过程中有一 些收获，贡献给教内外的同仁批评。由于本人不懂韩国文字，对于中文的 韩国研究论著也了解很少, 很担心有失礼之处, 悬请教内人士给予批评和 谅解2)。

\section{一、相生与和谐精神}

已经有学者对一百年来韩国新兴宗教的流派和历史分期做了很深入而且 全面的研究。由㽆山圣师开创的教派在韩国近现代历史中有着特殊的地 位。它当然也有其他宗教的时代特征。崔水云领导的具有鲜明民族精神的 东学运动最终失败了。后来属于賏山教派的许多领袖虽然也投身到了东学 的活动中，但是他们后来表现出不同的趋向。

有学者指出：“大多数的早期宗教运动一般都是以渴望旧世界的终结和 新世界的到来的民众期昐为基础而展开的，因而，都把类似这样的开辟或 者终结的迫切性当作动员民众的主要方法。3)”东学革命的结果是悲惨的。 金洪喆指出：“东学革命之后，在这一地区出现的甑山教运动，可以说是 这一地区历史和思想基础上形成的民族宗教运动的典型。㽪山教义缓解了 这一地区无法避免的民众的恨和抵抗意识，这一教义是为了成为真正的后 天仙境的主人、为韩国民众指出正确的选择道路的教义。4)”

of California Press), 2011. 需要指出的是日本政界和学界在战争期间就开始实地考察新 兴宗教的活动了。可以提供参考的是：兴亚院政务部编：『北支に於ける文教の現状』，兴亚 院华北联络部, 1941年。兴亚宗教协会：『华北宗教年鉴』，兴亚院华北联络部，1941年。 不过, 中国学者对这些材料认识还很不够。

2）在这个过程中，我也努力学习中国学者和韩国朋友们的著作。这些著作主要是已经收入 金勋教授编辑的『道与东方文化』文集中诸位教友的大作，以及金勋老师本人的著作『韩国 新宗教源流与嬗变』。韩国学者卢吉明等教授的『韩国民族宗教运动史』一书的中文译本给 了我很多帮助。本文中很多历史事件的知识是援引他们的论著的。我郑重感谢这些学者 给我的知识和启发。

3）『韩国民族宗教运动史』，第35页，中国社会科学出版社2009年出版。

4）同上书，第 91 页。 
『典经』记录了九天上帝的思想：“东学主张辅国安民, 强调后天之事, 实乃心中企盼成为王侯将相。如今非但未能如愿, 由此送命者达数万人之 多。这一怨直达苍天。若将这些怨种置之不理, 则逆度于后天, 致使政事 日趋艰难。吾念于此，正欲确定众神灵解怨头目。5)”

当然，也有学者指出䁬自山系新宗教使得以前的外部冲突的剧烈形式转变 为内在的神秘主义的形式。我认为，这样的缓解和转变在于䁬山先生的思想 表现了和谐的精种。这个和谐精神的集中体现就是“解冤相生”的思想。大巡 真理会的思想宗旨是 “阴阳合德、神人调化、解冤相生、道通真境”。这个 宗旨忠实地继承了赠山先生的思想。解冤相生的思想在『典经』里面有很多 体现。『公事』一章的开端部分就记载了九天上帝自己的解说：

在先天，人与世间万物皆为相克之理所支配，世间怨恨日积月累，错 综复杂地充斥于三界之中。天地失其常道，各种灾祸丛生，世间暗无天 日。因此, 吾欲整理天地度数, 调化神明, 以解万古怨恨, 以相生之道建 后天仙境，济度世间苍生。不论大小事应由神道解冤，若能事先稳固度数 并加以调化，人事便以神道为范实现自我达成，这便是三界公事也。6)

“天地公事” 的重要内容是解冤。解冤思想表达了有爷甑山圣师教派的 特殊历史观。这个思想也表现在其他教团那里, 是韩国新兴宗教的比较普 遍的思想。它可能有着久远的历史桬源。金勋教授指出它可能和韩国本土 的宗教传统有联系7)。

『典经』以解释远古的传说故事，说明了这一点。

人类有记录之初就积有冤，冤史初章之尧之子丹朱之冤若得解除，之后 数千年间所积冤结便可得解。尧以丹朱不省, 嫁二女于舜, 并托付天下。 丹朱因此怀冤，使舜死于苍梧，使二女溺沉潇湘江。从此冤之根深结于世 间，代代相续，冤种遍撒，时至今日积冤充斥天地间，导致人类行将毁

5）『典经简体本，第117页。大巡真理会出版部2010第一版。本文所引用的『典经』文字均出 于这个版本。

6）『典经』，第94页。金勋教授的著作中也有类似的一段引文。见其大作『韩国新宗教的源流 与嬗变』，第139页，宗教文化出版社2006年出版。

7）『韩国新宗教的源流与嬗变』，第139页。 
灭。因此，若救人类于此劫灾灭，不得不行解冤公事。8)

这个历史观要说明的是人类只有从根本上解除世代的怨恨才能进入幸福 安乐的时代。那个充满怨恨的时代就是所谓的先天。最近，大巡宗教文化 研究所的车瑄根教授对于中国古代的解冤思想作了研究9)。他对汉朝出现 的『太平经』里“解冤结”的思想和『典经』做了比较，对我很有启发。他的研 究说明的历史上很早就开始用“冤结”来解释社会矛盾，用“解冤结”的方法 舒缓族群冲突。『太平经』的作者在很早的时期就已经用“冤结”来说明社会 矛盾，并且主张以“解冤结”方法可缓解群体之间的冲突。

『太平经』还没有特别要解释往古历史的意思，更注目现状。怣于『太平经』 最早的传说就是讲『太平经』出世意味着上天要改换社会的命运10)。『太本 经』在中国宗教史上的意义就是宣传改天换地的思想。在这一点上，它和韩 国近代的民族宗教运动的“开辟”思想是一致的。这种改换劫运的观念是值 得我们继续研究的11）。

目前我们看到的韩国近代宗教思想有了很早就传来的弥勒救世的观念。 这个观念是外来的，不是东亚本土的思想。改换天地的思想至少在谶纬以 前的儒家典籍里也没有，也值得我们寻找它的起源。

『典经』解冤思想的特别之处在于它还强调“相生”。车瑄根教授对于“相 生”的理论作了很精到的阐述。我不能重复了。这个“相生”思想不仅和当 时的甲午东学革命相区别，而且和历史上很多宗教的解决怨恨的方法相区 别。车教授指出，甑山先生的基本精神是面向来者、面向生者。“潧山的 解冤所面对的主体，超越了亡者，扩大到了活着的人、民族、国家，甚至 包括动物与神明等所有存在于宇宙中的个体”12)。㬝山思想和以往各种宗

8) 『典经』，第125页。

9）他的论文收入了金勋主编的『道与东方文化, 宗教文化出版社 2012 年出版。车教授在论文 中指出郑在书教授早在1995年就研究『太平经』的解冤结思想了。

10）见『汉书』第75怣，中华书局标点本第10册，第3192页。

11）卢吉明教授特别指出了基督教的千年王国思想。见『韩国民族宗教运动史』，第33页。法国 道教学者Anna Seidel曾经利用基督教的这个思想对比中国南北朝道教的思想以及当时中国 北方的民众运动。The Image of the Perfect Ruler in Early Taoist Messianism, History of Religion9:2，1970. 王宗昱所译中文本『老子和李弘』发表在『国际汉学』第11辑, 大象出版社2004年出版。 
教的区别就是不仅仅解除历史上的旧冤，更着重消除当代的怨恨。解决过 去的怨恨，也可以使用相克的办法，但是解决当代的怨恨如果使用相克的 办法就会增加新的怨恨。消除当代怨恨的办法就是“以善报恶”。

『典经』里记载潧山对信徒们说 : “汝等皆应回心转意, 弃复仇之念。如 今乃解冤时代，当以善报恶。倘若汝等不弃此意，必将于后天播下恶 种。13)”所以，赠山先生及其后学特别加以注意的是如何建立新的社会秩 序，对传统社会里的妨碍人际和谐、容易产生怨恨的旧习惯加以改造和消 灭。『典经』也反映了罾山在这方面的努力和贡献。

潧山圣师建立了一个有高度争容性的世界观。他说：“吾所行之公事, 于古于今未篔有也，既非继承他人，又非运数所定，唯吾所能者也。吾将 主宰三界之大权，改定先天之度数，开后天无穷仙境，建设地上乐园。14)” 所谓三界，说明他是从全宇宙的角度来考虑思想体系的建设的。例如人尊 思想就是对于三界矢系的一个重要的创见。所谓改定先天度数，说明甑山 先生并没有简单地否定历史上的解冤传统，而且把解除历史怨恨看作为现 代人类准备的必要条件。『典经』记载上帝说：“因冥府发生错乱，世间随 之混乱不堪。故冥府公事完成，则世间万事皆可得解。15)”

值得注意的是䁬而山开辟后天的思想里特别体现了和谐的精神。首先他从 全球的高度强调要实现民族、国家和宗教之间的和谐。『典经』记载说： “上帝率一切道通神与文明神，取各民族文化之精髓加以统一”” “上帝又 道：因地气尚未得统一，故生活于地球的人类，所思有异而反目争斗。若 消这一矛盾对立现象，应通过解冤来调化万古神明，匡定天地度数。此公 事得成，则天地开辟，展现后天仙境。16)” 在东亚国家还很封闭而且遭受

12)『道与东方文化, 第401页。

13) 『典经』，第263页。

14）『典经』，第94页。

15）『典经』，第95页。『典经』还记载了为万古逆神解冤，为当代亡者如崔水云解冤。这些为亡 者解冤的做法在历史上其他宗教里也有传统。例如道教有解“塚讼”的仪式。相爸研究可以见 美国学者柏夷(Bokenkamp)和(Nickerson)等人的研究。Stephen Bokenkamp, Early Daoist Scriptures (University of California Press), 1997.

16）『典经』，第323页，125页。 
西方国家侵略的时代，甑山先生能够提出主张并且预见到未来的世界应该 是一个和谐的、相互学习的局面, 是他的伟大之处。今天我们看到了全球 化的进程在最近三十年有了新的变化，不仅东亚工业文明证明了古老文化 的新的生机，也使得西方民族逐渐重视工业落后地区的文化的价值。

其次，轠山圣师对于传统文化中容易造成人间隔圂与怨恨的旧习惯做了 革除。这些变革突出表现了平等的观念。据『典经』记载：“上帝曰：当今 乃解冤时代。贵两班而分别尊卑，犹如掘租坟而毁族。故速废两班之因 习，善待贱人，冤方得解，迎和平盛世。17)” 两班制度是朝鲜王朝时代形 成的官僚系统并演变成社会等级。㽪山先生顺应时代的变化，对两班传统 提出质疑: “若阶级低下, 复所食有别, 岂不生怨恨乎?18)” 这显然是一种 思想革命。这个思想废除了旧时代的等级观念, 主张人人平等。噌山看到 贵贱、贫富以及强弱等社会差别容易造成人们之间的怨恨和矛盾。『典经』 里有几处记载到他对这些问题的明确看法，倡导消除这些差别。

“在后天，弱者得助，患者痊愈，贱者提升，愚者得智。19)”这些主张当 然也是和他的人尊思想直接联系的。人尊思想是新时代的人文主义。倡导 社会本等只是人尊思想的一个侧面。社会本等就是希望人们反省以前各种 彼此有冲突的见解和立场，实现彼此的和谐相处。

甑山对旧文化的改革还表现在一些日常生活方面的细节。『典经』记载 说：“上帝废除了古已有之的师徒之间的礼数, 并准许从徒们在上帝面前 平坐和吸烟。20)” 朝鲜王朝是儒教大发展的时期。儒教是一个有着繁文桭 节的文化，更是一个以等级制度为特征的文化。㬝山不仅在上面这个小节 方面做了改革, 他更倡导男女本等21)。总之，潧山所倡导的宗教思想 就 是消除人们之间的矛盾冲突，创造和谐相生的社会环境。

17）『典经』，第234页。

18）『典经』, 第258页。

19)『典经』，第249页。

20) 『典经』, 第82页。

21）参见『典经』第105、246、258页。 


\section{二、宗教文化和谐精神}

我们已经看到『典经』里说到赠瓦山先生“取各民族文化之精髓加以统一”。 我们当然也会看到『典经』里记载的对某些宗教的批评，但是总的说来他对 各个宗教是宽容的，并且很认真地吸收了自己所提倡的思想和有爸资源。

『典经』还说道：“丁西年，上帝再一次开学塾于郑南基家中，教授弟弟 永学、亭烈之子赞文以及邻里孩童。这一时期，上帝通读了儒佛仙以及阴 阳谶纬类书籍，以此为匡救天下之参考。22)” 这个记录说明䁽山先生的思 想背景就是多元的。这个背景也是反映了中国和朝鲜历史上的思想资源。

在中国历史上，俗称的儒道佛“三教” 是被看作社会上得到普遍承认特别 是受到官方承认的宗教。而所谓“阴阳谶纬”则是和不同时期不同地区的思 想融合在一起的文化，也是不甚受到官方承认的文化。例如所谓“阴阳”比 较多地势和民间方术融合在一起，而在汉代得到皇帝推崇的谶纬种学从隋 朝开始被官方排斥甚至禁毁，但是在民间则流传甚广。提到韩国的宗教传 统，常常见到“儒佛仙”的说法，类似中国人习惯说的“儒道佛”。这说明韩 国也习惯把这三个宗教作为在社会上居主要地位的宗教。曾瓦山也不例外, 遵从了历史上的习惯说法。

辛京元来谒上帝。上帝道：吾知汝来。便取来一张洋纸，让京元写上儒 佛仙三字。上帝在儒字旁写下尼丘，佛字旁写下西域，仙字旁写下苦县 后，将其烧掉。23)

这说明甑山先生也是把所谓三教看作是最主要的宗教和文化形态。

尽管噌瓦山先生被尊为“九天应元雷声普化天尊”, 反应出道教元素的重要 性，不赾我仍然认为在他和他的教派的思想体系里可能佛教的元素更为重 要。是否恰当? 还请教门人士批评并原谅。

22）『典经』，第17页。据李能和记载：鹠山幼年时候“常独读仙道之太乙咒、佛典之『七星经、 及儒籍之『尚书序』。见朝鲜道教史』，第497页，普成文化社出版。

23）『典经』，第84页。 
见于『典经』的寺院至少有十所。最重要的当然是金山寺。它和甑山圣师 的创教活动有密切的联系。金山寺是韩国历史悠久的佛教寺院24)。有爸㬝 山教团的佛教元素最重要的内容是䏌于九天上帝的身份的记载：“上帝位 居九天，神圣、佛、诸菩萨等向上帝诉求，皆谓匡扶天地之纷乱非上帝不 能。于是，上帝降于西洋大法国天启塔，环视三界，大巡天下之际，至东 土朝鲜停留，临于母岳山金山寺弥勒金像凡三十年，降天命与神教于崔水 云，使其确立大道。后于甲子年收回天命与神教，辛未年亲临世间。25)” 金洪吉指出 : 百济灭亡以后，其遗民相继开展了以真表律师为中心的弥勒 信仰运动。这个运动一直持续到二十世纪。东学革命和甑山教都是这个运 动的表现26)。韩国学者把近代的民族宗教运动追溯到一千多年以前的源 头, 对于我们了解韩国宗教史乃至中国宗教史都有极大的启发和教六。李 能和把这种运动和信仰和“耶稣再临” 类比 27 )。我认为, 东亚的弥勒信仰有 很长久的历史。它当然和佛教的传入有密切的吴系, 但是可能又和我们通 常看到的佛教不同。弥勒信仰强烈地表达了民众对未来世界的憧憬，也暗 含着对现实的否定。

在中国的历史上弥勒信仰是民间秘密宗教的源头活水，召唤着一代又一 代的广大群众树立对未来的信心，激励着千百万劳苦大众起来反抗压迫。 在1949年以后的中国大陆，对秘密宗教的研究过分注意了弥勒信仰的反 抗精神，不过一些学者对于这些信仰运动的资料作了比较深入的整理和分 析。据马西沙教授研究，弥勒观念在汉朝末年经由佛经的翻译传到中国。 西晋时代的佛经翻译完整地介绍了弥勒净土思想。此后, 这个思想在发展 过程中还有大量伪造的经典推波助澜，使得弥勒救世的信仰在民间广泛流 传。我认为这个思想和一般的佛教思想有区别就在于它提出“释迦牟尼 末，更有新佛出”28)。

24）『韩国民族宗教运动史』，第88页。

25）『典经』，第321页。

26）『韩国民族宗教运动史』，第89页。李能和的『朝鲜道教史』列举了朝鲜历史上几次弥勒下 世的事件。

27）『朝鲜道教史』，第489页。㬝山本人也有类似自比，见『典经』第342页。 
『典经』里记载了那么多的佛寺，说明鉐山及其弟子和佛教的往来很多， 自然和佛教有良好的䏌系。他们当然也接纳了很多佛教的教义和仪轨。例 如『典经』记载赠亚山要求弟子们“须留意心、口、意所造一切罪业”29), 由此 可知，曾瓦山很重视佛教观念。他们对佛教教团的一些不良行为也作出批 评。例如曾瓦山曾经怒斥松广寺的某些僧人“假托佛法惑世诬民”30)。某些佛 寺也显然是他们经常活动的场所。『典经』记录了十处佛寺。曾瓦山也打出过 “弥勒佛教”的旗号31)。尽管如此，我并不认为醋山教派属于佛教。在中国 的经验，一个庙宇里的宗教活动往往和庙宇的称号的宗教性质并一致32）。

『典经』里面的儒家思想表现在几个方面。1, 曾瓦山圣师和道主对于儒家

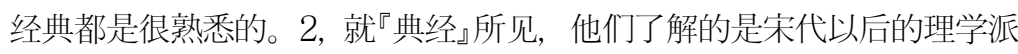
的儒家。3, 他们对儒家思想的理解和运用有自己的创造。『典经』的很多 地方引用儒家经典, 也记载道主曾经派人收集儒家经典33）。常见的是周易 和『大学』。

曾瓦山曾经会见易学大家及新兴宗教领袖金一夫34）。据说，赵鼎山道主 也曾经亲自去法庭上和地方法院院长进行『周易』论战35)。易学的名词在 『典经』中出现很多，和他们的日常生活和宗教活动有密切的矢系。

儒学在朝鲜王朝时代得到了极大的发展，特别是朱子学。这显然影响到 最近几百年朝鲜牛岛儒学的形态。据『典经』记载, 甑山先生对朱喜的著作 显然是很熟悉的。他曾经给属下背诵朱喜注解『大学』的文句36）。典经』

28）这个说法出现于唐立宗时代。而“新佛”的说法早在北魏(386-557年)就出现了。见马西沙 『中国民间宗教简史』，第19页，上海人民出版社 2005 年出版。我不反对李能和把弥勒和耶 稣相比，而且这种救世主降临世间的信仰的可能是从中东、波斯一直到印度都有的。我不 能确定它最早的源头, 需要进一步参考历史学家和宗教学家的研究。中国的弥勒信仰也曾 经结合来自波斯的摩尼教。可以参考马西沙和林悟殊的著作。

29) 『典经』, 第259页。

30) 『典经』，第6页。

31）吕春燕、赵岩：『韩国的信仰和民俗』，第266页，北京大学出版社2010年出版。

32）王宗昱: 『清代汉中地区的全真道, 收入『丘处机与全真道』, 中国文史出版施2008年出版。

33）『典经』，第225页。

34）参照『典经』，第17-18页。

35）分别见『韩国民族宗教史』，第23页，第174页。

36）『典经』，第170页。 
也反映出甑山教对于理学的历史很熟悉, 很看重 37 )。『典经』记录的㬝山文 字有云：“理虽高，出于太极无极之表，不离乎日用事物之间。38)”这应该 是朱喜的思想。『典经』记载的文字多出谈到太极或者太极图。这也是周敦 䝠一派的后学39)。

目前所见的儒家元素基本都是思想和典籍方面的，只有很少的文字说到 儒家的生活礼俗。例如成服祭40)。我检索『四库全书』没有成服祭这个词 汇。未知清朝末年是否有。在朱喜的『家礼』一书中成服的确是一个重要的 丧礼节目，但是没有特别的祭祀活动 41 )。『典经』里面记载了甑山对哭丧、 祭品和死者四代以后成“鬼”的看法42)。这不仅反映出甑山创建的宗教和以 往的宗教传统有割不断的吴系，也值得我们研究韩国的儒教礼俗和中国的 区别。

特别值得注意的是『典经』里矢于利用儒家经典治病的信仰。例如有人患 腹水病以后身体浮肿, 上帝为他念诵『大学』文句, 此人的病情很快好转。 还有一个故事是说背诵六十四卦治疗腿痛43)。不仅背诵儒家经典的经文可 以治病，背诵经典的注释也可以治病44)。这种治病应该是依赖了经典的神 力。『典经』记载上帝轓经对人说 : “回家扇屛子时, 读七星经咒文读到武 曲破军部分, 再读『大学』, 如此则可通于道术也。45)” 可见，读儒家经典

37）继承曾瓦山思想的鼎山曾写的“濂洛诸贤一时传道”, 同样表现出大巡思想对理学的认知程度。 参照『典经』, 第208页。

38）『典经』，第319页。

39）爷于太极图的传承及其与道教和儒教的兊系, 可以参考朱伯芘易学哲学史』, 上册第220页, 中册第89页，北京大学出版社1986年和1988年相继出版。

40) 『典经』，第123页。

41）这当然不排除民间实际流行的丧礼突出了这个节目。南宋人刘宰的『漫塘集』有两篇在成 服那天使用的祭文。见『漫塘集』第26卷，文渊图四库全书本。吕春燕、赵岩『韩国的信仰 和民俗』一书介绍了韩国民间的丧葬传统，基本属于儒家范畴，而且成服祭是一个独立的 节目。这值得中国学者在研究东亚丧葬文明时候认真讨论。见该书第296页。

42）『典经』, 第242页，243页。四世为鬼的说法在中国虽然在西晋时候就有挚虞的『决疑要 注』提出, 但是在后代的礼书里面并没有被当作重要议题。挚虞这部著作已经失散, 只能 见到后代的援引文字提到“四世为鬼”。我推测他可能主要是针对周代天子的祭祀制度而 言的。可以参考『礼记』。韩国这个观念的流行的确值得研究儒教历史的学者爸注。

43)『典经』, 第314页，309页。

44）『典经』, 第306页。

45）『典经』, 第280页。 
得到的效果和读其他宗教经典的效果是相同的。我在中国本土还没有看到 类似记载。当然, 典经』更宣传儒家经典的教育作用。上帝说：“多读『书 传』序文则通于道也；反复诵读『大学』上章，则能豁然贯通。”他的父亲读 了以后开发了智慧，帮助村民解决了困难46)。

我在『学习〈典经〉笔记』47)里面已经讨论过『典经』和道教文化的联系。 如何分析『典经』乃至噌山圣师创教过程中的道教因素呢? 李能和在介绍赠 山事迹时说他“常独读仙道之太乙咒、佛典之七星经，及儒籍之尚书序。” 又介绍太乙咒说 : “对此咒文，二说不同。一则姜一淳在金山寺读佛经时 得一道士所遗。一则黄帝所作，而老子修正云云。48)” 根据这个说法，太 乙咒大概是属于仙道范畴的。太乙咒的确是㬝山新兴宗教最重要的标志, 而且是仙道的标志。

甑山在“仙”字旁写下“苦县” 49), 当然是指老子的故乡, 也是把老子尊为 道教的教主。不过，他又自命或者被尊为弥勒佛50), 后来被道主尊称为九 天应元雷声普化天尊51)，显然并没有把自己的教团看作和中国一样的道 教。我认为噌山先生的教团还是有很多道教色彩的。这表现在他希望建设的 理想社会是“仙境”。“信我者可得永久福禄，长生不老，永享仙境之乐。52)”

他为什么在自命弥勒佛的同时还有另外两个道教的称号? 这的确是一 个值得研究的现象。普化天尊这个称号可能和朝鲜时代『玉枢经』的流传有 直接的䏌系。李能和的『朝鲜道教史』对此有介绍。㬝山使用的太乙咒语是 向太乙元君祈祷的。这个神在中国晋代葛洪的『抱朴子』里就出现了。

『典经』里记载的『玄武经』也反映出曍山圣师和玄武思想之间的连接性。 玄武信仰在中国历史很悠久，并不专属于道教，不过在北宋和明代由于皇

46）『典经』，第251-252页。

47）收入金勋主编的『道与东方文化。

48）李能和：『朝鲜道教史』，第498页。『典经』第154页提到在䁬山之前有一个名叫金京䜣的 人修行太乙咒已经五十年了。又见『韩国民族宗教运动史』，第23页。

49)『典经』, 第84页。

50) 『典经』, 第22页。

51) 『典经』，第210页。

52)『典经』，第279页。 
家的推动把它扩大到印度尼西亚的华人社会，一直到今天都在东南亚有广 泛的影响力。我看不到『玄武经』的全部内容，我认为它可能和其他地区的 玄武信仰肯定有不同的地方。『典经』展示的『玄武经』内容有儒家经典的目 录，这显然和目前收藏在中国正统道藏里的几部矢系到玄武信仰的经典根 本不同。不过，我暂时把它看作是接近仙道的。

『典经』文字里有大量的道教语言。由于中国和朝鲜在长久的历史中互相 影响，这些文字已经成为东亚的公共资源。例如，『典经』说㬝山出生的地 方古代有三座仙山53)。这是爸于海山仙山的古老传说，是中国、朝鲜、日 本共享的文学和宗教遗产。第二章里，金一夫梦见自己到了“天上玉京”拜 见天尊54）。这就显然来自道教的信仰。玉京山和三十六天的说法中国南北 朝时期形成，是最高的天界。

『典经』里涉及耶稣教和西方文化的内容也很多。特别值得注意的是把利玛 实当作西方文化的代表，给了他很高的地位55)。据学者们研究，利玛实没 有到过韩国，尽管他的学生徐光启在1620年曾经计划到韩国来。1603年, 朝鲜使节从北京带回了利玛实制作的地图56)。这时利玛实还在世。1613年 郑斗源来华，带回利玛实的『天主实义』等书57）。1783年，李承薰随父亲来 华，在华期间接受洗礼，回国不久就吸收两班弟子入教。待信徒增加到三十 多人时，创建了朝鲜教会。无论是西方学术还是西方宗教，大概朝鲜人最初 知道的信息都和利玛突联系着。

当然，利玛窦在其他新兴宗教里是否像在賏山教这样重要还要搜索材 料。我目前没有知识。㽪山有一段话很能表达利玛窦的形象：“西洋人利 玛窦来此东方，欲建地上天国，却因儒教根基深厚，积弊日久，改革难 行，终未能如愿。不过，利玛窦打通了天与地之间的界别，使各守一方、 互不越界之神明彼此开始往来。利玛窦死后，率东方神明前往西方，开启

53）『典经』，第2页。

54）『典经』，第17-18页。

55) 『典经』，第172页。

56）李元淳：『朝鲜西学史研究』，第74页，中国社会科学出版社2001年出版。

57）王春来：『基督教在近代韩国』，第7页，中国社会科学出版社2000年出版。 
文运。自此，地上神开始模仿天上一切妙法，将其施展于人间，西洋一切 文物实乃仿天国之模型矣。58)”

『典经』记载了几次甑山及他的弟子和耶稣教徒的不愉快的交往，也有负 面的评价59）。但是上面这段话显示㬝山作为思想领袖对西方文化是包容 的。他的立场是认为西方文化属于他将要建立的新世界的一部分。在几次 谈话里瞄山似乎把西方文化作为和需佛仙三教并列的一个新的文化元素。 这说明鳃山面对韩国近代新宗教运动的兴起能够顺应历史潮流，洞察到当 时的世界趋向并提倡宗教之间的和谐。他甚至明确说：“仙道、佛道、儒 道、西道乃世界各族属文化之基石。60)”

\section{三、对民间信仰与新宗教的包容精神}

基于『典经』的大巡思想仍然可以看作是类似中国的三教融合的系统『典 经』记录噌山的话说：“吾将道通脉传于大头领，告知成就道通之法。道通 之时，儒佛仙等道通神们将汇聚一堂，依据各自身心所修，通达于道。61)” 我认为这更是上层宗教领袖的思想体系。为了教导广大的下层民众，要满 足广大信徒的需要。弥勒信仰的成分就表明它并不是正统佛教的观念，而是 宣传未来救世主要下凡普渡众生的。所谓谶纬和后天开辟思想也是顺应了民 众的这个愿望的。后天开辟思想是对历史上过去迷信的罭纬传统的一个现代 改造和积极的引导。对这方面的历史知识我了解很少，仅仅谈几点。

首先，我们看看㬝山的活动和民间巫教的爸系。『典经』记载：“上帝将 金京学家定为大学校, 说道: 学校中以此为大, 如今是解冤时代, 宜先传

58）『典经』，第147-148页。

59）『典经』，第40页、第252页。

60）『典经』，第172页。

61）『典经』，第162页。 
教于贫贱之民。遂令京学叫来六位巫师。上帝令众巫师脱掉祓冠，在每人 面前摆上一碗清水, 连拜四次, 而后上帝诵三遍侍天咒。仪式结束后, 上 帝一一问他们的姓名, 并令其将清水喝下, 说道: 此福禄也。进入解冤时 代，上帝首选贫贱之人传教。62)” 这个故事实际上是讲甑山改造收编地方 宗教。䁬出山还在“巫堂度数”的意义上开展有矢活动, 『典经』记载了上帝“行 巫堂度数”的活动63)。赠山也擅长告祀仪式。而告祀是韩国民间普遍流行 的传统宗教仪式64）。

其次, 㬝山在他的思想中吸收了很多民间流行的神灵崇拜。例如，遇到雨 天泥泞，上帝就写符命令“道路神哷”来自帮助65)。这类神明是在民间流传 久远的崇拜对象。这类神明还有灶神、司命、饿芓神、马将军、白衣君王、 黄泉神。吸收了这些民间神明，也吸收了和这些神明有爸的各种法术。

这些法术主要表现为用咒语和烧符命令这些神明做事。见于『典经』记载 的咒语有二十多种。这些咒语来源不同。我曾经指出过『九灵三精咒』应该 是道教咒语。当然也有新创造的咒语如侍天咒。这当中也会有一些咒语的 来历是民间信仰。例如『五方咒』或许和遁甲有爸系66)。我也看到『典经』 列出的咒语很复杂而且又系统，不像是民间的简单易行的咒语。由于我没 有看到更多的咒语，所以我暂时不排除某些咒语来自民间长久流传的信 仰。至于对符的神力的崇拜，是人类的久远信仰。神符在信仰治疗当中的 作用可以在『典经』里看到很多实例。这里暂不罗列。甑山思想吸收了这些 民间信仰，就能满足下层民众的需要，方便传教和扩大影响。

我希望把七星和爸炣的信仰都放到这部分里来谈。我不能确定这些信仰 在中国和古代朝鲜时代的宗教特质。前面介绍有韩国学者把『七星经』看作 佛教的范畴。李能和的『朝鲜道教史』有专门一章讨论七星问题。他是把七

62)『典经』，第159-160页。

63) 『典经』，第138页。

64）『典经』，第77页。参见『韩国的信仰与民俗』，第243页。

65）『典经』，第279页。

66）『典经』，第220页。可参考的文献是『遁甲演义』，文渊阁四库全书本。秉梧的论文对『典 经』中的遁甲做了初步研究，可以参考。见『道与东方文化。 
星信仰看作佛道杂糅的现象。他指出朝鲜佛寺里常有七星阁，也有专门的 仪式。他有列举皇家拜七星的仪式中有盲人诵经，而盲人诵经是“道流系 统”67)。目前我在精读『典经』的过程中可知在七星信仰中诵读七星经咒文 的重要性。不能判断属于哪一类宗教，所以把它列入民间信仰。李能和还 指出民间下葬时候使用到七星板68)，试图追溯七星信仰的远源。我认为他 的努力给我们启发，七星信仰在民间的流传很值得探讨。

目前学术界的䏌公研究比较注意爸炣信仰和佛教的吴系69)。俄罗斯汉学 家李福清教授收集了许多地方的民间传说。他是把爷犲信仰看作一个在民 间广泛传播的信仰，不看重哪个教团吸收了它。爸犲后来被崇拜为武圣 人，和孔夫子比肩，说明这个信仰有很强的独立性。目前在中国民间除了 商业人士把他作为财神来崇拜，很多民间教团特别是信仰扶恋的现代宗教 团体很相信䏌公的灵验。最近中国学者孙为国发表了『朝鲜王朝䏌王庙创建 本末与矢王崇拜之演变』，对爸犲信仰进入朝鲜的经过做了详细的考察，值 得我们学习。他指出, 䏌犲信仰大约是由明朝军队带到朝鲜的。1597年, 明朝军队为了中国军人的需要在今古岛建立第一座矢帝庙70)。以后，朝鲜 皇帝为了加强和中国的吴系把矢帝崇拜列入国家祭祀。孙为国把这以后的 爸帝崇拜历史分为三个阶段。第一个阶段是在朝鲜确立爸公信仰的时期, 第二个阶段是繁荣发展时期，第三个阶段是向民间传播并且本土化的时 期。第三个时期大约从1801年开始计算，或许在民间会更早一些时间。

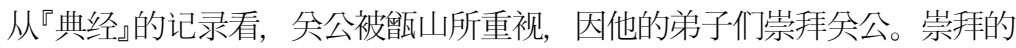
基础就是灵验。『典经』记录的两座吴帝庙似乎都不是噌山教团所有的庙，

67）李能和说：“按『李朝实录』，世宗大王为母后病，聚盲僧(道流僧)行桃枝精勤，即今俗盲 人读经之本原也。”朝鲜道教史』，第464页。

68）『朝鲜道教史』，第477页。他对棺木里七星板的使用引证的材料不够早，至少需要追溯到 『颜氏家训。

69）爸于笑公信仰的研究情况，可以参见周努鲁『知雅仰研究的回顾与探讨』，刊于中国人 民大学『宗教研究』2012年刊，宗教文化出版社出版。卢晓衡主编的『吴狋、爸公和䏌圣』 也汇集了矢公研究的论著目录，社会科学文献出版社2002年出版。

70）『韩国研究论从』第二十二辑，第39页，世界知识出版社2010年出版。2013年8月在北京 大学举行的会议上韩国学者金一权发表的『朝鲜后期兊圣教的敬信修行论』给了我很多新的 信息。 
而是向全社会开放的爸帝庙。这样说来, 那里的崇拜人群是来自不同的群 体的。甑山让其门徒相信祭祀吴帝会得到帮助。所谓“云长咒” 就是招呼爸 犽和其他种哷来保护自己，驱除邪鬼71）。

最后, 我要谈谈㬝山教和东学运动的䏌系。在 ${ }^{\circledR}$ 典经』当中记录最多的宗 教爸系就是和东学的吴系。一方面, 㬝山先生本人和门徒和东学的成员经 常有往来72)。另一方面，东学的咒语“侍天咒” 是圙山教派的人经常使用 的。曍山发起新宗教运动之后, 一些门徒对东学党有负面看法73), 也自然 会造成互相之间的隔圂。因此, 㬝山圣师宗教运动的发展和东学组织有密 切的联系。

㬝山对东学运动有辩证的看法: “有兴乱之人方有纾乱之人。虫尤作乱, 造浓雾, 黄帝以指南车治其乱。无论兴乱还是纾乱者, 皆为造化。因此, 崔济愚乃作乱者, 吾为治乱者。全明淑则令天下乱起而动之矣。74)” 他把全 明淑列为古今名将的范畴, 说明他能够站在很高的角度上评价东学运动及 其领袖的历史地位。这也是他把崔水云任命为神界的仙道宗长与日本冥府 的理由。他当然也对东学有严肃的批评, 但是他对崔水云等人的评价以及 对东学党人的接纳不能被看作是简单的怀柔和利用。䁬山教团的兴起对于 纾解东学革命的悲惨结局有伟大的历史功绩 75)。他吸收了很多东学的资 源, 例如“侍天咒”、“水云歌辞”, 以及“六任”制度等76)。对于转入㽪山教 门的东学党人残存的不良习惯, 甑山也身体力行地感化他们 77 )。这不仅改 变了新兴宗教运动的社会形象，也和谐了来历不同的教徒之间的吴系。

71）例见『典经』第294页，第155页。

72）卢吉明指出：鲴山教“是在东学运动展开得最活跃的地区, 以参加过东学革命的成员为中 心发展起来的”。『韩国民族宗教运动史』, 第8页。

73）例见『典经』第253页。

74）『典经』，第269页。

75）参见『韩国民族宗教运动史』，第91页。

76）『典经』，第331页。

77）『典经第151页记载上帝变卖自己的财产分给乞正，感化一进会成员告别了甲午年间抢掠 民众的恶习。 


\section{【參考文献】}

『典经』, 韩国：大巡真理会出版部, 2010年版。

『遁甲演义』，文渊图四库全书本。

『漫塘集』, 文渊图四库全书本。

『汉书』, 中华书局标点本

金一权, 「朝鲜后期䏌圣教的敬信修行论」, 『韩国研究论丛』第22辑, 世界知识 出版社，2010年版。

金勋, 『韩国新宗教的源流与嬗变』，北京：宗教文化出版社，2006年版。

金勋 主编, 『道与东方文化』, 北京: 宗教文化出版社, 2012年版。

吕春燕、赵岩, 『韩国的信仰和民俗』, 北京：北京大学出版社, 2010年版。 卢吉明 等, 『韩国民族宗教运动史』, 北京：中国社会科学出版社, 2009年版。 卢晓衡 编, 『䏌狋、䏌公和䏌圣』, 社会科学文献出版社, 2002年版。

李能和, 『朝鲜道教史』, 韩国：普成文化社出版, 1977年版。 李元淳, 『朝鲜西学史研究』, 北京：中国社会科学出版社, 2001年版。 马西沙，『中国民间宗教简史』，上海：上海人民出版社，2005年版。 王宗昱 译, 中文本『老子和李弘, 『国际汉学』第11辑, 大象出版社, 2004年版。 王宗昱，「清代汉中地区的全真道，『丘处机与全真道, 中国文史出版社，2008年版。 王春来，『基督教在近代韩国』，北京：中国社会科学出版社，2000年版。 周努鲁, 「笑犲信仰研究的回顾与探讨」, 中国人民大学 刊, 『宗教研究』, 北 京: 宗教文化出版社, 2012年版。

朱伯崑, 『易学哲学史』, 上册、中册, 北京大学出版社, 1986、1988年版。 兴亚院政务部 编、『北支に於汁文教の現状、兴亚院华北联络部, 1941年版。 兴亚宗教协会, 『华北宗教年鉴』，兴亚院华北联络部, 1941年版。

『韩国民族宗教运动史』，中国社会科学出版社，2009年版。

Stephen Bokenkamp, Early Daoist Scriptures, University of California Press, 1997.

The Image of the Perfect Ruler in Early Taoist Messianism, History of Religion9:2, 1970.

V. Goossaert and D.Palmer, The Religious Question in Modern China, The University of Chicago Press, 2011.

V. Palmer and Liu Xun eds., Daoism in the Twentieth Century, University of California Press, 2011. 
-국문요약-

\section{대순사상의 종교 문화 조화정신}

\section{왕쭝위(王宗昱)}

북경대학

한국은 백 년 이래로 군사적 침략과 경제적 대변혁을 맞았으며, 또한 종 교와 문화적 측면에서 전통의 중흥기와 서학의 유입에 대한 문제를 경험 하게 되었다. 이런 점에서 한국의 역사적 경험은 주변 국가의 국민들이 배 울 만한 의미가 있다고 생각된다. 이와 연관하여 대순진리회가 역사를 계 승하고 창신을 이루어나가는 측면의 문제는 정리해볼 만한 가치가 있다.

대순진리회의 종지는 ‘음양합덕, 신인조화, 해원상생, 도통진경’이다. 특 히 대순진리회는 해원상생 사상으로 조화정신을 집중적으로 잘 나타내고 있다. 대순진리회의 해원은 고대 단주로부터의 원을 푸는 것에서 시작되 며, 인류가 근본적으로 여러 세대에 걸친 원한을 풀어야만 행복하고 안락 한 시대에 진입할 수 있다는 역사관을 보여주고 있다. 대순진리회가 해원 을 푸는 방책으로 제시하는 상생은 당시의 갑오동학혁명이나 역사상 많은 종교에서 원한을 해결하는 방법과 구별되는 것이다. 과거에 있어서는 상 극의 방법으로 원한을 해결하여 왔으나, 상극의 방식은 오히려 새로운 원 한을 더욱 만들어 낼 수 있기 때문에, 현대에 있어 원한을 제거할 수 있 는 방법은 악을 선으로써 대하는 것이라고 한다. 증산 성사 및 그 후학들 은 사회의 질서를 새롭게 세우는 문제와 전통사회에서 인간 간의 조화를 방해하고 원한을 용인하는 구습을 개조하고 원을 소멸하는 문제에 주의를 기울였다. 이러한 변혁은 평등의 관념을 나타내고 있다.

증산께서는 전 세계적인 관점에서 민족과 국가 그리고 종교 간의 조화 를 실현해야 할 것을 강조하셨다. 당시 동아시아 국가는 매우 폐쇄적인 상황에서 서양 국가의 침략을 받던 시기였는데, 증산 성사께서 미래의 세 
계는 마땅히 화합을 이루고 서로의 장점을 배우는 세계가 될 것임을 예견 하셨다는 것은 그의 위대함을 보여주는 대목이다.

증산의 후천개벽사상 역시 조화의 정신을 나타내고 있다. 후천개벽사상 은 전통적 참위를 현대적으로 개조한 것으로 민중을 적극적으로 인도하기 위한 것이다.

다음으로, 증산께서는 각 종교에 대해 관용적인 태도를 표하셨고, 또한 매우 진지한 태도로 타 종교로부터 자신이 주창하는 사상과 관련한 자원 을 흡수하셨다. 동양의 전통적인 유불선 삼교를 가장 중요한 종교와 문화 형태로 인정하시고, 그 삼교의 내용을 두로 포용하셨으며, 심지어 예수교 와 서양문화까지 모두 아우르는 태도를 보여주셨다. 서양의 문화 역시 증 산께서 추구하시는 신세계의 한 부분이었기 때문이다. 이러한 사실은 증 산께서 당시 세계의 역사적 방향에 대해 통찰하고 있었고 이 통찰 속에서 종교 간의 관계가 조화롭게 되어야 함을 주창했음을 말해 준다.

대순사상에는 민간 무교의 내용 역시 풍부하게 들어있다. 부뚜막신, 사 명, 아표신, 마장군, 백의군왕, 황천신 등 민간에서 유행했던 다양한 신령 숭배의 내용을 흡수했을 뿐만 아니라, 주문과 부를 태우는 법술로 신명과 관련된 내용을 표현하고 있으며, 칠성과 관우의 신앙까지 수용하고 있다.

또한 증산 성사는 동학과 같은 신종교까지 받아들이셨다. 증산께서는 동학혁명의 비참한 최후를 완화시켰던 위대한 역사적 공적을 이루셨으며, 신종교 운동의 사회적 형태를 변화시켰을 뿐 아니라, 서로 다른 내력을 지닌 교도들간의 관계를 조화롭게 하였다.

이로 볼 때 결국 증산께서 주창한 대순사상은 사람들 간의 충돌과 모순 을 소멸시키고, 조화와 상생의 사회 환경을 창조하고자 하는 것이었다고 할 수 있다.

주제어 : 대순사상, 상생, 조화정신, 증산, 신종교

(0) 투 고 일 : 2013년 8월 31일

(0) 심 사 기 간 : 2013년 11월 18일 22일

(0) 게 재 확 정 일 : 2014년 3월 9일 